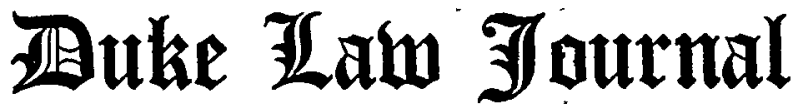

VoLUME I960

SUMMER

NUMBER 3

\section{DIME STORE DEMONSTRATIONS: EVENTS AND LEGAL PROBLEMS OF FIRST SIXTY DAYS}

\author{
Daniel H. Pollitrt*
}

F DWARD P. MORGAN: I wonder if you consider the current Ghandi-like passive resistance demonstrations of $\mathrm{Ne}$ groes in the South as worthy of identification as manifestations of moral courage, or whether you disapprove of them?

President Eisenhower: Now, let me make one thing clear. I am deeply sympathetic with the efforts of any group to enjoy the rights, the rights of equality that they are guaranteed by the Constitution. ... If a person is expressing such an aspiration as this in a perfectly legal way, then I don't see any reason why he should not do it. ${ }^{1}$

In $\mathrm{I} 865$, the thirteenth amendment was ratified, ending the institution of slavery. In 1866, to eliminate the burdens, disabilities, and incidents of slavery, Congress passed a Civil Rights Bill securing to the Negro "those fundamental rights which are the essence of civil freedom."2 Among these fundamental rights guaranteed the Negro is "the same right, in every State and Territory, as is enjoyed by white citizens thereof to inherit, purchase, lease, sell, hold, and convey real and personal property."3 In 1866, Congress proposed the fourteenth

*A.B. 1943, Wesleyan University; LL.B. 1949, Cornell University. Member of the New York and District of Columbia bars; Associate Professor of Law, University of North Carolina. Contributor to legal periodicals.

${ }^{1}$ N.Y. Times, March 17 , 1960, p. x6, col. x.

2 The words are those of Mr. Justice Bradley in the Civil Rights Cases, rog U.S. I, $22(1883)$.

${ }^{3} 44$ Stat. 27 (1866), 42 U.S.C. $\$ 1982$ (1958). Congressman Trumbull, the sponsor of the bill in the House of Representatives, explained its necessity as follows: "That the result of the recent war, and the enactment of the measures to which the events of the war naturally led us, have intensified the hate of the controlling class in the insurgent States toward our colored citizens is a fact against which we can neither shut our ears nor close our eyes. Laws barbaric and treatment inhuman are the rewards 
amendment so as to incorporate this fundamental right of civil freedom "in the organic law of the land" and to eliminate doubt as to its constitutional validity. In I868, the fourteenth amendment was ratified, guaranteeing to all persons "the equal protection of the laws" and "the privileges or immunities of citizens." Among the "privileges and immunities" guaranteed the citizen is "protection by the government, with the right to acquire and possess property of every kind."

The constitutional promise of equality in opportunity has been broken to the hope. The congressional efforts in I 866 to guarantee the freed Negro equality with others in the purchase of real and personal property has been thwarted. As long ago as 1872 , Booker T. Washington, born a slave, experienced racial discrimination when attempting to purchase the necessities of life. Setting off by stage from his home in West Virginia to study at the Hampton Institute on the Atlantic shore of Virginia, he was denied shelter and food when the coach stopped for the night at a remote hotel in the mountains. He was forced to walk the hills all night long to keep warm. On the second night of the trip, the coach stopped in the capital city of Richmond. Again, rebuffed in his efforts to obtain a night's lodging, the young boy found shelter under the elevated wood planks then forming the cities' sidewalks. ${ }^{6}$ Were Booker T. Washington to make the same trip today, he would find the situation but little improved.

Throughout the South, the hotels, motels, restaurants, and lunch counters discriminate on the basis of color. ${ }^{7}$ In some few instances, this discrimination is required by statute or city ordinance. ${ }^{8}$ In most instances, it is a matter of custom and tradition, and fear of losing white business if Negroes are served.9 The degree of discrimination varies

meted out by our white enemies to our colored friends. We should put a stop to this at once and forever. And yet $I$ would not do this in a way which would deprive a white man of a single right to which he is entitled. I would merely enforce justice for all men; and this is lawful, it is right, and it is our bounden duty." Cong. Globe, 39th Cong., Ist Sess. III8 (1866).

Hurd v. Hodge, 334 U.S. 24 (1948).

The words are those of Mr. Justice Washington in Corfield v. Coryell, 4 Wash. C.C. $37^{1}$ ( 1823$)$, a case arising under the privileges and immunities clause in art. IV, $\S_{2}$ of the Constitution. The words were quoted with approval in the Slaughter-House Cases, 83 U.S. ( 16 Wall.) $36,7^{6}(1873)$, where the Court first construed the purpose and meaning of the privileges and immunities clause of the fourteenth amendment.

- Mathews, Booker T. Washington 42 (1948).

${ }^{7}$ Greenberg, Race Relations and American Law 80 (1959).

${ }^{8}$ See, e.g., VA. CODE ANN. $\$ 18-327$ (1949), as contrued in Nash v. Air Terminal Serv., 85 F. Supp. 545 (E.D. Va. 1949); Durham, N. C., Code $\$ 42$ (1947).

${ }^{\circ}$ In the university village of Chapel Hill, North Caroliua, where the student body 
from area to area and from store to store. In some instances, no service is given Negroes. In other instances, Negroes may be permitted to purchase food to take out and eat off the premises. In still other instances, the Negro customer may eat while standing, but not while sitting; or he may be permitted to sit at the counter, but not in a booth.

\section{The Events}

On February I, I960, four Negro students at North Carolina A. \& T. College in Greensboro, North Carolina, decided to do something about this unequal treatment. It all began in September 1959, when freshmen Ezell Blair and Joseph McNeill, both seventeen years of age, were assigned as roommates. They, and two other freshmen in their dormitory, spent much time discussing some of the segregated situations to which they were exposed. On Sunday evening of January 3I, I960, one of the boys said 'We've talked about it long enough, let's do something." The something was a walk to the dime store and an attempt to get coffee. The manager said he could not serve them because of local custom, so they just sat and waited. The only trouble that first day came from the Negro help who came out of the kitchen to tell the boys, now known on their campus as the "four freshmen," that they were doing a bad thing. Other students from the college were shopping in the store at the time, and when the four freshmen returned to the campus, twenty students volunteered to join them for the next afternoon. Ground rules were drawn up by the expanded group. There was to be absolutely no name-calling by Negroes, no raised voices, no word of protest if they were not served.

Again, Tuesday they were refused service. They just sat. On Wednesday and Thursday, they returned, in greater strength each time. The A. \& T. students were joined by many students from the Negro

forms the bulk of the restaurant patronage, the students, by poll and student body resolution, demonstrated an overwhelming desire for the termination of discrimination against Negro students. Three of the restaurants ended segregation some years ago, but the other restauranteurs refused to do likewise with the statement that "individually they were in no position to take any action." One such restauranteur cited his "high class waitresses" as the main reason for his discriminatory policy. Daily Tar Heel (University of North Carolina, Chapel Hill, N. C.), March 3, 1960, p. 2, col. I.

Some restauranteurs refused to end discrimination on the theory that serving Negroes would require the installation of two new toilet facilities: one for colored men, the other for colored women. There is no statutory enactment requiring racially-segregated toilet facilities in restaurants, although there is such a requirement in manufacturing establishments in North Carolina cities with a population of over one thousand. N.C. Gen. Stat. § 95-48 (1958). 
Bennett College and also by a few students from the white Woman's College of the University of North Carolina, both located in Greensboro.

By Friday, white teenagers had begun heckling the demonstrators. On Saturday, the Woolworth store was jammed with Negroes and whites. The Negroes mostly sat, while the white boys waved Confederate flags, chanted, and cursed. Around midafternoon, the management received a bomb threat, and the police emptied the store. When the store opened Monday, the lunch counters were closed. Dr. Gordon Blackwell, Chancellor of the Woman's College, proposed a "truce period" which was accepted to work things out in a less inflammatory atmosphere. Thus ended temporarily the Greensboro demonstrations; but by that time, Negro students were demonstrating in Winston-Salem, in Durham, in Charlotte, and the other principal North Carolina cities. ${ }^{10}$

The demonstrations in their origin were student-inspired and directed. Subsequently, organizations such as the National Student Association, the Congress of Racial Equality, and the National Association for Advancement of Colored People offered their guidance and sponsorship. ${ }^{11}$ In some instances, the help of these organizations was accepted; in other instances, the students decided to go it alone.

The reasons prompting the demonstrations have been expressed by the student leaders in various forms. Leaders in Greensboro, where the demonstrations originated, wrote the state Attorney General that "this mass movement was begun to bring to the realization of the citizens of North Carolina that the Negroes, who are also citizens of North Carolina, can no longer remain quiet and complacent and continue to accept such gross injustice."12 The student leader in Charlotte explained that the demonstration there was a "means of expressing something that has been in our hearts for a long time."13 High school students in Chapel Hill carried signs saying "We do not picket just because we want to eat. We can eat at home or walking down the street. We do picket to protest the lack of dignity and respect shown us as human beings." 14

\footnotetext{
${ }^{10}$ N.Y. Times, March 26, 1960, p. 10, col. 6.

${ }^{11}$ Author Harry Golden of Charlotte, N.C., commented that, "If the NAACP and every other do-good organization disappeared from the face of the earth tonight, the movement would not skip a beat." Durham (N.C.) Morning Herald, March 20, 1960, $\S$ A, p. 8, col. 4 .

${ }_{12}$ N.Y. Times, March 6, 1960, p. 3, col. 2.

${ }^{13}$ Durham (N.C.) Morning Herald, March 14, 1960, § A, p. 2, col. 8.

${ }^{14}$ Chapel Hill (N.C.) Weekly, March 24, 1960, p. 4, col. 1.
} 
The demonstrations struck a responsive chord in the hearts of Negro students elsewhere. Many of them mentioned the lack of progress in ending school desegregation as a reason for their presence on the lunch-counter picket lines. The struggle against school segregation took place in the courts, and required money, endless patience, and an appreciation or understanding of delicate legal moves and counter-maneuvers. The struggle against lunch-counter segregation required only courage and an ability to "turn the other cheek."15 As a result, students in Durham, in Charlotte, in Winston-Salem, in at least sixteen North Carolina cities began "sit-ins" or picket-line demonstrations at downtown chain drug and dime stores. ${ }^{16}$ The demonstrations moved northward into Virginia and West Virginia; south into South Carolina, Georgia, and Florida; and west into Tennessee, Kentucky, Alabama, Louisiana, Arkansas, and Texas. Pickets even appeared before those stores and restaurants in Ohio which violated the state equal accommodation laws by denying service to Negroes. ${ }^{17}$ The Raleigh News and Observer commented that with the arrest of demonstrators in that city, "the picket line now extends from the dime stores to the United States Supreme Court and beyond that to national and world opinion."

The European press gave wide coverage to the demonstrations. Communist radios and newspapers in Eastern Europe hit the discrimination theme hard, and even newspapers ordinarily friendly to the United States were critical. For example, the Austrian Socialist Party's Daily Arbeiter Zeitung published a front-page criticism of American racial discrimination, with a cartoon depicting a gorilla-like Southern white refusing service to a Negro girl. The cartoon was captioned "That is a free country."19 Both the Kremlin's Pravda and the Vatican's Osservatore Romano gave front-page headlines to the story of how white men in Houston, Texas, captured a Negro youth and carved $\mathrm{Ku}$ Klux Klan initials on his chest and back. ${ }^{20}$ The Rev. Dr. Billy

${ }^{15}$ The writer is informed that demonstrators in High Point, Chapel Hill, and other cities in North Carolina have classes in the techniques of nonviolence, and are required to pledge passive resistance before they can participate in the picket lines. Many students at North Carolina College in Durham withdrew from the activities when they discovered they were unable to "take" the vilification and abuse sometimes meted the demonstrators.

${ }^{10}$ Durham (N.C.) Morning Herald, March 20, 1960, § A, p. 12, col. 2.

${ }_{17}$ N.Y. Times, March 3, 1960, p. 15, col. 1.

${ }^{18}$ Raleigh (N.C.) News \& Observer, March 16, 1960, p. 8, col. 2.

${ }^{10}$ N.Y. Times, March 4, 1960, p. II, col. 1 .

${ }^{20}$ Id., March I1, 1960, p. 14, col. 4; id., March 9, 1960, p. 19, col. 1. 
Graham, conducting a two-day religious crusade in Ethiopia, was asked almost exclusively about this matter at a press conference. ${ }^{21}$

In the North, religious, labor, and liberal organizations and individuals spoke out in support of the demonstrations. Delegates to a fourteen-state Midwestern Democratic conference adopted a proposed civil rights plank demanding equal rights for all Americans in voting, education, housing, and service at lunchrooms. ${ }^{22}$ Earlier, Mrs. Franklin D. Roosevelt had called the demonstrations "simply wonderful"; and United Auto Workers' president, Walter Reuther, had called on the President to restore law and order in Alabama so picketing could be resumed in Montgomery. ${ }^{24}$ The greatest and most vocal support, however, came from the college students. This issue aroused the present campus generation-often accused of self-concern and pallid indifference to social or political questions-as have few others. Vassar girls picketed for the first time in twenty years; and student groups at Harvard, Yale, Brown, Chicago, Wisconsin, Colorado, and other campuses sprang up over night to picket the local branches of the chain stores that discriminated in the South. ${ }^{25}$ Student groups at Wesleyan University, Harpur College, and elsewhere set about raising scholarship money and bail funds to assist the Negro students expelled or imprisoned because of participation in the demonstrations. ${ }^{26}$

In the South, the most vociferous support for the demonstrations came from the clergy. Ministers, Negro and white, singly and in association, defended the spirit and purposes of the demonstrators. One such minister wrote that "the Negroes now confront us with the Constitution in one hand and the Bible in the other. ... Why do we not grant these rights gracefully and with good will?'”27 A national Protestant Episcopal organization said that "such demonstrative witness, motivated by love and expressed in nonviolent, passive resistance to evil, is thoroughly grounded in Christian teaching."2s The Rev. Dr. Ernest

${ }^{21}$ Reverend Graham answered that, "Such horrible acts are a stumbling block in the Christian world, are detestable and should be forthrightly condemned by all Christians." Id., March II, I960, p. I4, col. 4.

22 Raleigh (N.C.) News \& Observer, March 28, r960, p. I, col. 6.

${ }^{23}$ She also expressed opposition to sympathy boycotts in the North where the stores were not segregated. N.Y. Times, March 23, 1960, p. I8, col. 3 .

${ }^{24}$ Id., March $\mathrm{r}_{3}$, z 960, p. 43 , col. 5.

${ }^{25} I d$., March 20, 1960, p. I, col. 2.

${ }^{26}$ The students called this a "more constructive expression of our support than picketing a dime store." Id., March 22, 1960, p. 20, col. 1; id., March 19, 1960, p. 9, col. 3 .

${ }_{27}$ Durham (N.C.) Morning Herald, Feb. II, I960, \$A, p. 4, col. 5 .

${ }^{28}$ N.Y. Times, March 6, 1960, p. 74 , col. 3 . 
Trice Thompson, the highest elected officer of the Southern Presbyterian Church, said that the demonstrations were serving to call attention to "discriminations which should be forgotten and which will pass. All discriminations will, and must, disappear."28a Former United States Representative C. B. Deane, now president of the North Carolina Baptist State Convention, told a group of ministers that Baptists "cannot tiptoe around the racial issue," and that "in order to reach the Cross and solve the wave of sit-downs, ... the South . . . must be willing to pay the price of personal change."28b The Durham, North Carolina, Ministers Association pledged support to the management of local stores if there be a decision "to inaugurate a policy of food-service without regard to race" and promised "to encourage the community at large to accept such a policy."29 The Chapel Hill, North Carolina, ministers simultaneously issued to their congregations a "Statement of Convictions" that stated in part that "we deplore the fact that any group of our citizens is placed in the position of having to ask to be treated with dignity and respect. ${ }^{30}$

The clergy was not alone in its support of the demonstrators. Florida's Governor LeRoy Collins told a state-wide radio and television audience that "I don't mind saying that if a man has a department store and he invites the public generally to come in his department store and trade I think then it is unfair and morally wrong for him to single out one department, though, and say he does not want or will not allow Negroes to patronize that one department.”31 Frank P. Graham, who formerly served North Carolina in the United States Senate and as president of the University of North Carolina, told a United Nations model assembly that the Negro demonstrators find that "in sitting down they are standing up for the American dream" and said the Negro students are "in their day and generation renewing springs of American democracy." ${ }^{32}$ The North Carolina AFL-CIO in state convention went on record im support of the Negro efforts to get desegregated lunch

\footnotetext{
${ }^{282} I d$., March 28, 1960, p. 26, col. I.

${ }^{28 b}$ Greensboro (N.C.) Daily News, March 24, 1958, p. I2, col. 4.

${ }^{20}$ Durham (N.C.) Morning Herald, March I5, 1960, § B, p. I, col. 3.

${ }^{30}$ Chapel Hill (N.C.) Weekly, March 24, 1960, p. 4, col. 2. These and similar statements so alarmed the Mississippi legislature that it passed a bill aimed at preventing church integration. The measure authorizes the state chancery courts, upon petition of two-thirds of the membership of a congregation, to dismiss its trustees and appoint new ones should the trustees vote to bring Negroes into white churches. N.Y. Times, March 25 , 1960, P. I9, col. I.

${ }^{31} I d$., March 2I, I960, p. 37 C, col. I.

${ }^{32}$ Durham (N.C.) Morning Herald, March 13, 1960, § C, p. 1o, col. 6.
} 
counter service; ${ }^{33}$ and the North Carolina Student Legislative Assembly, representing seven Negro and eleven white colleges in the state, voted to ban segregation in eating establishments. ${ }^{34}$ The Greensboro Daily News said editorially: "There are many white people in the South who recognize the injustice of the lunch counter system. It is based on circumstances which may have made sense Ioo years ago; today it has a touch of medievalism. It smacks of Indian 'untouchables' or Hitlerian Germany's Master Race Theories."35 The Raleigh News and Observer editorialized that the racial line between counters in the same store is "fuzzy, twisting and uncertain" and commented that "no "now you see see it, now you don't' color line can be meticulously maintained." "30

Within two months the demonstrations had practical effect. In San Antonio, Texas, downtown stores opened their lunch counters to all persons, regardless of color, ${ }^{37}$ as did the stores in Galveston. ${ }^{37 \mathfrak{a}} \mathrm{A}$ bus station cafe in Nashville served several Negroes without incident, ${ }^{38}$ as did three drug stores in Salisbury, North Carolina. ${ }^{30}$ In WinstonSalem $^{40}$ and in Chapel Hill, North Carolina, ${ }^{41}$ as well as in Suffolk, Virginia, ${ }^{42}$ store managers removed stools and opened on a service-toall-who-stand-up basis. ${ }^{43}$ The Chapel Hill Mayor's Committee on Human Relations reports that "quietly and without fanfare, several restaurants began offering equal service to Negro customers." Lenoir, North Carolina, Negro students were permitted to make use of the downtown library for the "first time within memory." How

${ }^{33}$ Id., March 19, 1960, § B, p. 7, col. 7.

${ }^{34} I d .$, March 20, 1960, § A, p. 8, col. 4 .

${ }^{35}$ Greensboro (N.C.) Daily News, March 29, I 960, p. 8, col. I.

${ }^{36}$ Raleigh (N.C.) News \& Observer, March 16, 1960, p. 8, col. 1.

${ }^{37}$ N.Y. Times, March 20, 1960 , p. 1, col. 2.

${ }^{372}$ Id., April 6, 1960, p. I, col. 8.

${ }^{38}$ Durham (N.C.) Morning Herald, March 17, 1960, \$ A, p. 2, col. 7.

${ }^{39}$ Raleigh (N.C.) News \& Observer, March 13, 1960, \$ III, p. 2, col. 7.

${ }^{10}$ Ibid.

"1 Durham (N.C.) Morning Herald, March 27, 1960, § A, p. 6, col. 2.

${ }^{4}$ N.Y. Times, March 19, 1960, p. 9, col. 3.

${ }^{43}$ The Charlotte (N.C.) Observer, March 13, 1960, § III, p. 2, col. 7, commented that "some future logician will be baffled by an ancient logic that it was all right for a man to stand up and eat next to a person of another color but all wrong to eat sitting next to him." The future logician will be troubled also by the mores which permit complete and courteous service to the department store Negro customer in the lingerie, millinery, and shoe departments, but which draw, the line at giving any service in the food departments.

* Durham (N.C.) Morning Herald, March 27, 1960, § A, p. 6, col. 2.

${ }^{45}$ Id., March 23, r960, § A, p. 8, col. 4 . 
many more establishments have "quietly" opened their facilities to Negroes cannot be known.

Most Southern opinion was against the demonstrators. Lunchroom proprietors generally held fast to traditional policies. Public officials warned against participation in the demonstrations. Students in some areas were expelled from college and in others threatened with expulsion. In a few instances, planned mass prayer meetings were thwarted by use of fire hoses, tear gas, and mass arrest. With a few notable exceptions, the press was generally critical. ${ }^{40}$ The details of the opposition are highlighted on a state by state basis.

\section{Alabama}

The demonstrations reached Alabama on February 25, when thirtyfive Negro students from Alabama State College asked for service in the Montgomery County courthouse snack shop. ${ }^{47}$ The shop closed immediately. The sheriff soon arrived with a club in hand and ordered the Negroes to line up in single file. While pistol-carrying deputies patrolled the halls outside the basement shop, state highway patrolmen took pictures of the Negroes who stood quietly against the wall. Governor John Patterson ordered an investigation and indicated that the students would be expelled. The following day the Police Commissioner warned that any sit-down would be considered a "breach of the peace" and that his department would not permit efforts to foment violence; the Governor ordered the President of Alabama State College to expel any student involved in a sit-down; and the Negro students held a campus rally to consider mass application at the white state institutions should a Negro student be expelled..$^{48}$

On February 27, a Negro woman was attacked by one of a group of

\footnotetext{
${ }^{46}$ The following report is taken from the N.Y. Times, March 6, 1960, p. 3, col. 3 : "The Southern press has generally deplored the demonstrations. But some editors have found the Negroes a cut above the whites who turned out to torment them. The Richmond News Leader said Virginians must have 'felt a twinge of wry regret' over circumstances surrounding a 'sit-in' in that city. The newspaper continued: 'Here were the colored students, in coats, white shirts, ties, and one of them was reading Goethe and one was taking notes from a biology text. And here, on the sidewalk outside, was a gang of white boys come to heckle, a ragtail rabble, slackjawed, black-jacketed, grimning fit to kill, and some of them, God save the mark, were waving the proud and honored fiag of the Southern States in the last war fought by gentlemen: Eheu! It gives one pause.' "

${ }^{67}$ N.Y. Times, Feb. 26, 1960, p. 8, col. 3. It is unconstitutional for such a lunchroom to deny service to Negroes. Derrington v. Plummer, 240 F.2d 922 ( 5 th Cir. 1956), cert. denied, 353 U.S. 924 (1957).

${ }^{48} I d .$, Feb. 27, x960, p. 20, col. $\mathrm{x}$.
} 
twenty-five whites who patrolled the streets carrying miniature baseball bats inside paper bags. Negroes made plans for a mass "hymn-singing, prayer session" protest. $^{49}$

On March I, a thousand Negro students sang the national anthem on the Capitol steps, ${ }^{50}$ and a Negro minister told the audience "I am proud to be a member of a generation that is willing to stand on the roof tops and tell the world that they want to be free."

On March 2, nine Negro students were ordered expelled for taking part in the demonstrations, the Governor commenting that such action was necessary "to prevent bloodshed in this city."

On Sunday, March 6, approximately 800 Negroes left their churches for a demonstration prayer meeting at the State Capitol grounds. A jeering mob of whites charged the marchers, and a riot was narrowly averted when the police separated the two groups, and mounted deputies and fire trucks moved in to prevent further violence. The march had been announced two days earlier, and at the appointed time, high city, county, and state officials, fifty highway patrolmen, mounted sheriff's deputies, and two fire trucks were on hand. When the Negroes left the church, the firemen pointed their hoses at the Negroes, and policemen pushed them back as they started in the direction of the capitol building. ${ }^{\text {s }}$

On March 8, a scheduled campus protest meeting was broken up when police arrived and arrested thirty students and one faculty member standing in the student crowd. Two other students were jailed while trying to get in to see the students already under arrest. ${ }^{54}$

In the following days, students at Alabama State College held another campus demonstration against the arrests (this time without incident); Negro youths in Huntsville in northern Alabama marched silently through the business section bearing antisegregation signs; and students at Tuskegee Institute stayed away from class in sympathy protest. On March Io, the Montgomery Police Commissioner recommended the closing of Alabama State College and accused it of turning out "graduates of hate and racial bitterness."

On March II, the Montgomery City Court convicted thirty-two

\footnotetext{
${ }^{10} 1 d$., March $\mathrm{x}, \mathrm{x} 960, \mathrm{p} .2 \mathrm{x}$, col. 3.

${ }^{50}{ }^{1 d}$., March 7, 1960, p. 1, col. 3 .

${ }^{61}$ Id., March 6, 1960, p. 3, col. 1.

"Id., March 3, 1960, p. 15, col. 1.

${ }^{53} I d$., March 7, 1960, p. 1, col. 3 .

st Id., March 9, x960, p. 19, col. x.

${ }^{5}$ Id., March 11, 1960, p. $\times 5$, col. 4.
} 
Negro students of disorderly conduct. The judge delayed sentencing, which could amount to six months in jail, and the attorney for the defendants told the court that the student body at Alabama State College had agreed to return to class and stop the racial demonstrations. ${ }^{56}$

On March 22, seven Negroes applied for enrollment at the University of Alabama Extension College in Montgomery. The applications were the first in Alabama since Autherine Lucy was driven from the University of Alabama campus by a mob. ${ }^{57}$ By March 25, the number of applications had risen to thirteen. The University of Alabama is under court injunction not to bar any applicant on grounds of race. ${ }^{58}$

\section{Arkansas}

Arkansas joined the list of southern states hit by demonstrations on March Io, when about forty-five students from Philander Smith College entered a Little Rock variety store and sat down at a white lunch counter. The incident ended without violence when Police Chief Gene Smith recommended closing the counter. Most of the Negroes left quietly, but five who refused were seized on charges of disturbing the peace. ${ }^{59}$ On March I7, the five Negroes were convicted under a 1959 state law that prohibits causing a "breach of the peace" at a public place. Each of the Negroes was fined 250 dollars and sentenced to thirty days in jail. Immediately thereafter, other Negro college students sat down at five all-white lunch counters but left when store officials asked them to do so. ${ }^{60}$

\section{Florida}

The demonstrations began in this state on February 26 with a sit-in in Tallahassee. Eleven Negro students were arrested and charged with disturbing the peace. ${ }^{61}$ Ten days later, forty Negro youths staged a sit-down protest at a Tampa Woolworth lunch counter. The counter was closed without incident. ${ }^{62}$ The sit-ins quickly spread to St. Petersburg, Sarasota, and Daytona Beach. No violence was reported, and none of the Negroes received service. ${ }^{63}$

On March 3, Governor LeRoy Collins termed sit-down demonstra-

\footnotetext{
${ }^{60} I d .$, March 12, i96o, p. 15, col. 4.

${ }^{87}$ Id., March 23, 1960, p. 18, col. 3 .

${ }^{\circ 8}$ Adams v. Lucy, 228 F.2d 6r9 (5th Cir. 1955), cert. denied, 35I U.S. 93 I (1956).

${ }^{50}$ N.Y. Times, March 11, 1960, p. 15, col. 4 .

${ }^{00} I d$., March I 8, 1960, p. 23, col. I.

${ }^{01}$ Id., Feb. 27, 1960, p. 20, col. x.

${ }^{02} I d$., March I, 1960, p. 2I, col. 6.

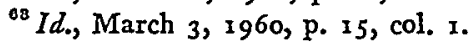


tions "illegal and dangerous" and said that a I957 law gave restaurant owners the right to refuse to serve anyone they considered undesirable. ${ }^{04}$

On March 4, eight ministers tried to enter a lunchroom in Miami's Burdine's department store, but were blocked by store employees. A cross was burned in front of a Negro home in Pensacola. ${ }^{65}$

On March I2, the demonstrations reached Jacksonville. Eight Negroes sat down at the lunch counter of a Kress's dime store. The counter was closed. The Negroes remained seated until seven policemen arrived and asked them to leave. They did. On the same day, there was near-violence in Tallahassee. A group of Negro and white demonstrators at a Woolworth store were arrested, replaced by another group that was arrested, and by a third group that was arrested. Shortly after noon, a crowd of about 125 Negroes gathered in a park across the street from the police station and started down the block toward the Woolworth store. Half-way there, they were met by a group of white men, turned and started back to their campus, while the whites followed with taunts and jeers. Off-duty policemen and firemen were stationed throughout the city to avert disturbances. ${ }^{\circ 6}$ On March I5, the Tallahassee City Commission warned that "those who violate the law will find we are prepared to take stern action." ${ }^{.07}$

On March I7, a group of eight students entered the Woolworth store in St. Augustine, the counter was closed, and when the Negroes left, they were attacked by a group of white men. Police called a cab to take the Negroes away, and the Chief of Police, armed with tear gas, ordered the crowd to disperse. ${ }^{08}$

On March 18, authorities at the white Florida State University in Tallahassee warned students against participation in the demonstrations, ${ }^{69}$ and, on the same day eleven Negro student demonstrators were convicted in Tallahassee on charges of disturbing the peace. Eight of them chose sixty-day jail sentences rather than pay the fines of 300 dollars. ${ }^{70}$

On March 20, Governor Collins declared in a state-wide radio and television speech that it is "unfair and morally wrong" not to allow Negroes to patronize one department of a store in which they are

\footnotetext{
os Id., March 4, 1960, p. Ir, col. I.

${ }^{\circ 5}$ Id., March 5, 1960, p. 10, col. 1.

${ }^{60} I d$., March ${ }^{2} 3,1960$, p. 43 , col. 4 .

${ }^{67} I d$., March I6, 1960, p. 27, col. 2.

${ }^{88}$ Id., March 18, 1960, p. 23, col. x.

${ }^{08}$ Durham (N.C.) Morning Herald, March I9, I96o, § B, p. 4, col. 6.

${ }^{70}$ N.Y. Times, March 19, r960, p. I, col. 8.
} 
invited to trade. He announced that he would appoint a state bi-racial advisory committee on racial relations and called upon the cities in Florida to take similar action. ${ }^{71}$ Within a week the Governor received a heavy volume of mail, mostly from Floridians, running eight-to-one in his support. The Governor received 2,381 favorable letters, 288 hostile ones. Nearly all the favorable mail was signed, and about a fourth of it came from clergymen, physicians, lawyers, and educators. About one-third of the unfavorable mail was anonymous, much of it scurrilous. ${ }^{\text {71a }}$

\section{Georgia}

On Friday, March 4, a small group of white and Negro students entered Rich's Department Store in Atlanta and were served at the lunch counter. The group was also served on Saturday, but on Monday, March 7, the group was turned away by store officials. ${ }^{72}$

On March ro, seven Negroes took seats in a white section of the Municipal Auditorium during a stage show. There was a brief verbal clash that ended when police designated the occupied section Negro. ${ }^{73}$

On March 15, approximately 200 students in Atlanta staged simultaneous sit-ins at noontime at the lunch rooms of the State Capitol, the Courthouse, the City Hall, the bus stations, the railway stations, two office buildings housing federal offices, and a variety store. Seventy-seven of them were arrested under a recent state law aimed at sit-down demonstrations making it a misdemeanor to refuse to leave private property when requested. ${ }^{74}$

On March 16, there was a "sit-in" in Savannah, and on March I7, following a big St. Patrick's Day parade, there were scattered fist fights and rock throwing between groups of whites and Negroes. Police and troopers patrolled the downtown business section, dispersing crowds and whisking troublemakers to jail. ${ }^{75}$

On March 26, white and Negro pickets marched in front of Rich's Department Store in Atlanta, scene of the first "sit-in," and 25,000 leaflets were distributed urging a boycott of stores with segregation policies. $^{76}$

\footnotetext{
${ }^{71}$ Id., p. 37, col. x.

71a 1d., March 30, 1960, p. 21, col. x.

${ }^{72}$ Id., March 8, 1960, p. I9, col. 3.

${ }^{73} I d$., March II, 1960, p. I5, col. 4 .

74Id., March I6, I960, p. 27, col. I.

${ }^{75}$ Durham (N.C.) Morning Herald, March 18, I960, § B, p. 8, col. 6.

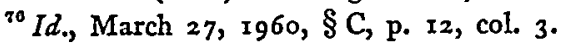




\section{Louisiana}

On March 8, the first public demonstration by Negroes in New Orleans took place on the campus of Dillard University. Spokesmen said the group had no plans to march on downtown New Orleans. ${ }^{77}$

On March I2, police in New Orleans arrested ten white youths in connection with cross-burnings on the campus of Dillard. ${ }^{78}$

On March 28, eight students from the all-Negro Southern University in Baton Rouge were arrested after they refused to leave a white lunch counter at a downtown department store. ${ }^{70}$ On March 29, nine additional Negro college students in Baton Rouge were arrested at lunch counters. The students at Southern University then decided to forego their junior and senior proms and use the dance money to finance future demonstrations. Governor Long commented that if the demonstrators "want to do any real good they should return to their native Africa." $" 10$

On March 30, I,000 students at Baton Rouge marched to the Capitol chanting "The Lord's Prayer." After singing "What a Friend We Have in Jesus," they disbanded without incident. ${ }^{81}$ The Southern University promptly suspended or expelled eighteen student leaders, and the students thereupon boycotted classes and more than two-thirds of them requested withdrawal forms. ${ }^{81 a}$

\section{North Carolina}

Greensboro in this state was the scene of the initial sit-ins, and at least sixteen other cities witnessed "sit-ins" and picketing, some of the picketing on a day-to-day basis over a period of many weeks. Despite the vigor of the activities, there was no violence, no tear gas, no fire hoses. Large groups of Negro students held prayer meetings on the steps of the state capitol ${ }^{82}$ and on the courthouse lawns at cities throughout the state with no other obstructions but jeers and catcalls. ${ }^{83}$ The picketing at Chapel Hill, typical of that in Durham and elsewhere, was described by a local newspaper in the following terms: ${ }^{84}$

\footnotetext{
${ }^{77}$ N.Y. Times, March 9, 1960, p. 19, col. 2.

${ }^{78}$ Id., March ${ }_{3}$, 1960, p. 43, col. 5 .

${ }^{70} I d$., March 29, 1960, p. 28, col. 2.

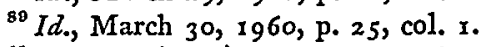

${ }^{81}$ Durham (N.C.) Morning Herald, March 31, r960, § A, p. 15, col. r.

${ }^{812}$ N.Y. Times, April r, r960, p. r, col. 4.

${ }^{82}$ Durham (N.C.) Morning Herald, March 15, r96o, § A, p. 3, col. 6.

${ }^{83}$ N.Y. Times, March 5, 1960, p. 10, col. 1.

${ }^{84}$ News of Orange County (N.C.), March 3r, rg6o, p. 1, col. 3 .
} 
The Chapel Hill police are more and more effectively controlling the weekday afternoon 90 minute sidewalk picketing demonstrations in front of a local drugstore.

Chief Blake has pre-set plans all ready to be put into action in the unlikely event of any disorder arising - and with each passing day this prospect seems less. But there are certain little innuendoes beyond the pale of legal control that pass back and forth between the opposing sides.

Smirks, sneers, frowns, smiles, the flicker of an eyelash meaningfullythese are some of the means of communication even though police rapidly control and largely prevent the passing of actual words or actions.

Picture-taking also figures significantly in the psychology of the affair. The picketers, committed to impassive silent marching, are about the mostphotographed subjects in all Chapel Hill during the last month. The other day one of the protest supporters, apparently just for the heck of it, pulled a new switch, and tried to photograph some of the spectators. The surprised and unwilling subjects fled pell mell before the lensman.

Some stores in Winston-Salem, Salisbury, Chapel Hill, and elsewhere ended racial barriers, ${ }^{85}$ and the mayors in Raleigh, Durham, Greensboro, and elsewhere established interracial committees to deal with the situation. ${ }^{86}$ Large proportions of the faculties at Wake Forest, Duke, and the University of North Carolina signed petitions urging the end of segregation and promising continuing patronage to those merchants who eliminated color bars at the lunch counter, and in Chapel Hill, a few University professors joined the Negro high school students on the picket line. ${ }^{87}$ Negroes were permitted to use the downtown public library in Lenoir for the first time within memory. ${ }^{88}$

Although there were no riots, no tear gas, no fire hoses, etc., there were shouts, shoves, near-crises, and arrests a-plenty. In Winston-Salem, twenty-two youths of both races were arrested when they refused to leave a restricted lunch counter in a Woolworth store. ${ }^{89}$ In Charlotte, three Negro demonstrators were arrested at the entrance to a basement cafeteria of Belk's Department Store. ${ }^{90}$ In Raleigh, forty-one students were arrested for trespassing on the sidewalks of a privately-owned

\footnotetext{
${ }^{85}$ N.Y. Times, March 8, I960, p. $2 x$, col. I.

${ }^{80}$ Id., March 5, 1960, p. 10, col. I; id., Feb. 27, I960, p. 20, col. I.

${ }^{87}$ Chapel Hill (N.C.) Weekly, March 24, 1960, P. I, col. 6.

${ }^{88}$ Durham (N.C.) Morning Herald, March 23, I960, $\S$ A, p. 8, col. 4.

${ }^{80}$ N.Y. Times, Feb. 24, 1960, p. 36, col. 6.

${ }^{\circ 0} I d$., Feb. 24, I960, p. 36, col. "7.
} 
shopping center. ${ }^{.1}$ In Durham, two students were arrested when they refused to take the sandwiches they had purchased outside to eat. ${ }^{22}$

There were other pressures put on the students in addition to the arrests. Chancellor Blackwell told the white students at the University of North Carolina Woman's College "to refrain from any public demonstration in connection with the issue now before the community or any similar issue which may arise in the future." ${ }^{133}$ Governor Hodges then wrote the presidents of all state-supported institutions enlisting their aid in curbing protest demonstrations, ${ }^{94}$ citing the Blackwell speech as

${ }^{01}$ Durham (N.C.) Morning Herald, Feb. 25, 1960, § C, p. 5, col. 1. In an analogous situation, the United States Supreme Court held in 1946 that application of the state's trespass laws to demonstrators on privately owned sidewalks unconstitutionally deprived the demonstrators of rights guaranteed by the first amendment. Marsh v. Alabama, 326 U.S. 496 (1946), discussed in text accompanying note 209 infra.

${ }^{02}$ Durham (N.C.) Morning Herald, March 26, 1960, § B, p. 1, col. 1. Judge Wilson, of Durham, acquitted the two students with the comment that "any owner can refuse to serve anyone he pleases, but once a person is served, regardless of his race, he has a right to eat it." $\mathrm{He}$ added that unless establishments display "For Whites Only" signs, all races may enter and request service. Durham (N.C.) Morning Herald, March 29, 1960, § B, p. 1, col. 7 .

${ }^{83}$ Greensboro (N.C.) Daily News, March 27, 1960, § C, p. 5, col. 1. A more complete statement of the Chancellor follows:

"And now, what are your responsibilities as students of the Woman's College in a controversy such as this?

"First, it should be clear that in this college there should never be any effort to tell you what stand you should take on controversial issues or how you should assert your inalienable rights as individuals and as citizens. . . . But your responsibility as students of Woman's College goes beyond personal considerations. Your class jacket is a symbol of the college. On and off the campus you represent this institution. Your actions bring credit or discredit to the college. You are not living in a social vacuum unencumbered by duties and responsibilities. The results of your actions may affect many others in a kind of chain reaction as has been painfully demonstrated last week.

"There is no blinking the fact that participation in this demonstration by several of our students, no matter how high their motives, definitely resulted in increasing the inflammatory quality of the situation .....

"And so, you see, your every action as an individual must be considered in a social and institutional context. You must each search out in advance the series of unanticipated consequences of any action which you may contemplate. Somewhere between putty-like conformity on the one hand and irresponsible, martyr-like revolutionary action on the other, each individual must find for himself or herself the best way of meeting any controversial situation. ...

"I strongly urge each of you to weigh carefully the probable consequences to yourself, to the college and to the community of any action that you may contemplate. More specifically, I advise each of you to refrain from any public demonstration in connection with the issue now before the community or any similar issue which may arise in the future. It is only in an atmosphere free from pressure and emotionalism that a fair and just solution may be found."

${ }^{04}$ N.Y. Times, March I1, 1960, p. 15, col. 4. At a press conference, the Governor 
evidence of the type of influence he wanted other administrators to use. ${ }^{85}$

At the end of the first sixty days, Negroes in Greensboro resumed their sit-in strikes, ending a cooling-off period in the city where the demonstrations originated. During the truce, the Mayor's Advisory Committee on Community Relations received over 2,000 communications discussing the problem. Seventy-three per cent of these favored equality of service on some basis, and the Committee suggested that the dime stores designate a section of the lunch counter for integrated service and another section of the counter for whites only. This suggestion was rejected by store managers, who feared a loss in profits if it was adopted. ${ }^{96}$

\section{Ohio}

The demonstrations spread as far north as Ohio. ${ }^{87}$ Negro students picketed variety stores in Cincinnati and were scolded by Governor DiSalle for not first bringing their complaint to the attention of the Ohio Civil Rights Commission.98 Picketing continued, however, and in Xenia, Ohio, Geyer's Restaurant opened its doors "to everyone" after approximately Ioo Negro and white students engaged in a peaceful Sunday demonstration. ${ }^{99}$

\section{South Carolina}

In this state, the demonstrations began on February 23 in the city of Rock Hill, when Ioo Negro students from Friendship College staged a

told reporters he had called the attention of heads of all state-operated colleges and universities to the portions of the Blackwell remarks quoted in note 93 supra. Reading a prepared statement, the Governor further said: "As I have previously stated, I do not think these demonstrations do any good, or in the final analysis will even serve to accomplish the objectives of the demonstrators." In answer to a question, the Governor said he was referring to Negroes who "cause disorder or refuse to obey an order to leave either by the owner or a police officer." Southern School News, April i 960, p. 13, col. I.

${ }^{\circ E}$ The writer has been reliably informed by faculty members at the Negro North Carolina College that, following the Governor's announcement, many students received letters from home telling them to stop demonstrating and keep out of trouble.

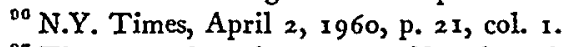

${ }^{07}$ They spread as far west as Nevada, where a threatened sit-in at the Las Vegas resort hotels was called off when the management agreed to end the existing color bar. Id., March 25, 1960, p. 18, col. 6.

${ }^{08}$ The Governor said: "If we are going to establish government according to law, the people should first exhaust the avenues supplied by law before they take upon themselves the creation of disturbances and attempting to injure anyone." Id., March 3, 1960 , p. I 5 , col. I.

${ }^{D 0}$ Id., March 9, 1960, p. 19, col. 2. 
sit-in in two variety stores. ${ }^{100}$. This was followed by demonstrations at the same stores by a robed $\mathrm{Ku} \mathrm{Klux} \mathrm{Klansman} \mathrm{who} \mathrm{promised} \mathrm{future}$ visits. ${ }^{101}$

On March 2, fifty Negroes trudged through an icy drizzle in Columbia, stopping briefly at the Woolworth and Kress stores. ${ }^{102}$ The next day approximately 200 Negro students marched around in the Columbia downtown area for nearly two hours. They were heckled by white youths and left at the request of the City Manager who wanted to avoid "an explosive situation."103 On March 4, the students in Columbia agreed to discontinue their demonstrations. But in Sumter, twenty-six Bible-carrying students were arrested for breach of the peace when they tried to get served at three stores. Bond was set at roo dollars each, and the Sheriff said he would see that no businesses there would have to close because of such demonstrations. ${ }^{104}$

On March 15, approximately I,000 demonstrators from Chaflin and South Carolina State Colleges converged at noon in downtown Orangeburg to protest lunch-counter segregation. The police met them with tear gas and fire hoses. Some 350 drenched demonstrators were arrested for breach of the peace and put in the courthouse yard behind a ten-foot high fence in the forty-degree weather while they awaited questioning. Those who could meet bail were released; those who could not were put into waiting buses and taken to jail. Magistrate Culler said he planned to try the students in groups of five, ten, and fifteen with the comment that "it will probably take all night." While awaiting their fate, the students broke into song. Their favorites: "God Bless America" and "Nobody Knows The Trouble I've Seen."10s

\section{Tennessee}

Chattanooga was the scene of the first Tennessee demonstration, when Negro high school students staged a sit-in in the Kress store. Rioting broke out when whites, mostly students, began throwing flower pots, dishes, bric-a-brac, and other merchandise in the store. One white youth grabbed a bull whip from the store stock and used it on a Negro. The Negroes retreated through the streets to a Negro section of the city, with bricks and other objects being hurled by both sides. After

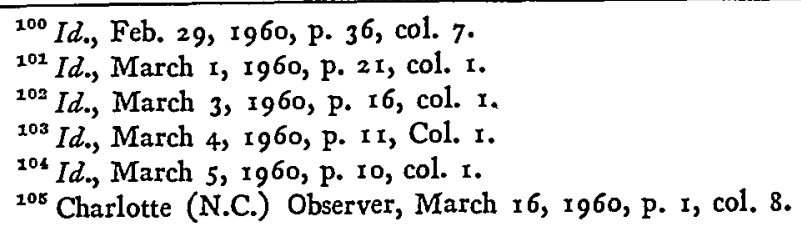


the fighting had subsided, white youths walked through the aisles of the Kress and other stores, jeering at Negro customers and frightening many into leaving. Some of the leaders said their purpose was "to run the niggers out." Seven whites were arrested, the police concentrating on the leadership. ${ }^{106}$ Mayor Olgiatti immediately conferred with white and Negro clergymen, who issued separate statements calling for an end to hostile acts. The Negro high school students decided against further demonstrations. ${ }^{107}$

The demonstrations next spread to Nashville. A white youth was sitting with a group of Negroes at a dime store lunch counter when a second white youth walked in, called him a "nigger-lover," and twisted his collar. The assailant then fled, but returned five minutes later. This time, he grabbed the sitting white youth, threw him on the floor, and kicked him. The police then ordered everybody to leave the counter. Eleven Negroes who refused to comply were arrested. ${ }^{108}$ The next day some seventy-six Negro and four white students demonstrated at downtown lunch counters and were arrested. A crowd of up to 3,000 Negroes thronged the courthouse for the trial, were told to leave the courthouse, and gathered on the courthouse steps, where they sang "The Star Spangled Banner" and "The Battle Hymn of the Republic."109 Two days later, fifty-five more Negro students were arrested, this time for refusing to leave the lunch counter at the Greyhound bus station when the Assistant Fire Chief asked all persons to leave the building while a search for a bomb was made. ${ }^{110}$ A Negro divinity student was expelled from Vanderbilt University for his part in the demonstration. ${ }^{111}$ The next day, March 4, warrants were issued against eighty students charging them with conspiring to violate the state trade and commerce law by helping to direct lunch-counter demonstrations. ${ }^{112}$ Two weeks later, shortly after the Nashville bus station served Negroes in the white restaurant, two dynamite caps-but no dynamite-were found in the washroom. ${ }^{113}$

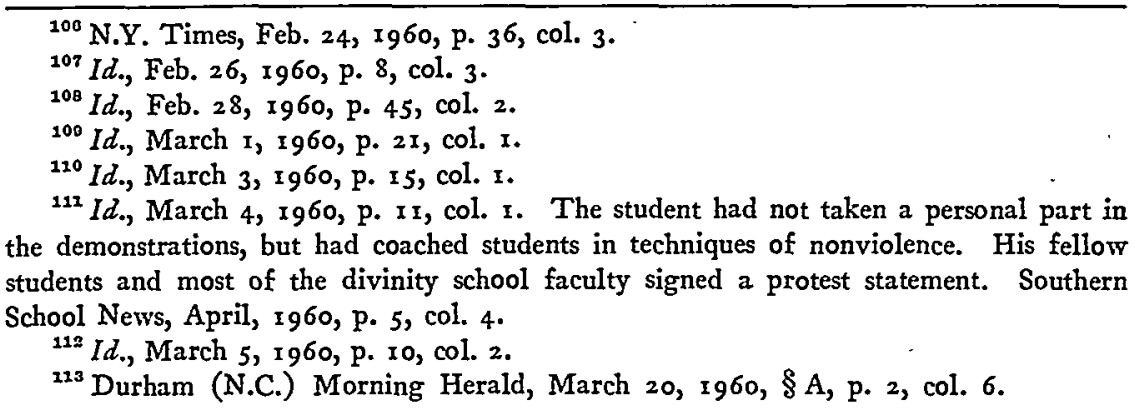


In Memphis, the demonstrations were centered around the library and art gallery. Negroes were permitted to use the reference room at the main library, but not the reading room. On Saturday, March I9, thirty-six Negro students went into the reading room. They and a Negro newspaper editor were arrested and convicted for disorderly conduct on the allegation that the students disturbed other persons when interviewed by the editor. The editor testified he "spoke in low tones" and was covering the story. ${ }^{114}$ The City Art Gallery is open to Negroes only on Thursdays. Seven Negro students entered the art gallery on a Tuesday and asked to see a special exhibit. They were directed to it and were examining the pictures when the police arrived and arrested them for "loitering" when they refused to leave as directed. ${ }^{115}$ The next day, a two-week cooling off period was agreed upon to allow time for efforts to settle racial grievances. ${ }^{116}$

\section{Io. Texas}

The demonstrations in Texas resulted in extremes-either of violence or of peaceful settlement.

The sit-ins began in Houston, mostly by Negro students from Texas Southern University, with immediate repercussions. A Negro drugstore porter was slashed by a white youth with a knife, ${ }^{117}$ and three masked white men seized another Negro, flogged him with a chain, carved the insignia of the $\mathrm{Ku}$ Klux Klan on his chest and stomach, and hanged him by his knees in an oak tree. The sit-in demonstrations then moved from the lunch counters near the Texas Southern University campus to the downtown drug stores. ${ }^{118}$

In the east Texas city of Marshall, demonstrations began on March 27, when twenty-five Negro college students were arrested when they sought service at three lunch counters. ${ }^{110}$ On March 30, about fifty-five Negroes were arrested for demanding to be fed at white lunch counters. While the first group was being fingerprinted, photographed, and charged with unlawful assembly, about 200 Negroes gathered near the courthouse and began to sing "God Bless America" and similar songs. The firemen then arrived and turned powerful streams of water into the crowd. Hoses drenched West Houston Street, which leads to

\footnotetext{
${ }^{114}$ N.Y. Times, March 22, 1960, p. 25, col. 1.

${ }^{118}$ Id., March 23, 196o, p. 18, col. 3 .

${ }^{110} I d$., March 24, 1960, p. 25, col. 1 .

${ }^{112}$ Id., March 8, 1960, p. 21, col. I.

${ }^{118}$ Id., March 9, 1960, p. 19, col. I.

${ }^{119}$ Id., March 29, 1960, p. 28, col. 2.
} 
Marshall's two all-Negro colleges. ${ }^{120}$ On April I, there were further student demonstrations, and forty-nine students were arrested for "unlawful assembly to deprive a man of the right to do business." Bail was set at 700 dollars each, and twenty-six of the girls, including the Chairman of the National Student Council of the YWCA, were confined for twenty-six hours in a single ten-by-twelve foot cell, without room to sit down. ${ }^{120 a}$ A Negro professor was fired for his part in the demonstration, and on March 3I, Governor Price Daniel asked the head of the Texas Department of Public Safety "to find out whether Communists were behind the Negro demonstrations at Marshall."121

In contrast with the situations in Houston and Marshall is that in San Antonio. Through the intervention of the Rev. C. Don Baugh, executive director of the San Antonio Council of Churches, downtown dime stores agreed to serve Negroes. Few Negroes took advantage of the situation, "but as they requested service there was no incident. Whites accepted the new situation calmly."122 In Galveston, too, lunch counters were voluntarily integrated, and Negroes started eating beside whites without incident. ${ }^{122 a}$

\section{r. Virginia}

The demonstrations began in Richmond with a sit-in at the restaurant in Thalhimer's department store. Thirty-three participants were arrested, which prompted a picket line urging a boycott. ${ }^{123}$ The Virginia legislature, then in session, enacted three antitrespassing laws aimed at the sit-down protests. They provide maximum penalties of $\mathrm{I}, 000$ dollars fine and twelve months in jail. ${ }^{124}$ These statutes did not punish picketing, and the line of protesters continued outside Thalhimer's. ${ }^{125}$

The protest demonstration ran a course similar to that in other states. It spread to variety and drug stores, first in Richmond, then in Suffolk, Portsmouth, ${ }^{126}$ Petersburg, ${ }^{127}$ Hampton, Newport News,

\footnotetext{
${ }^{120} I d .$, March 3x, 1960, p. I, col. 2.

${ }^{1200}$ National Student Councils of the YMCA and YWCA release, April 6, rg6o.

${ }^{121}$ N.Y. Times, April I, rg6o, p. 1, col. 4.

${ }^{122} I d .$, March 20, I960, p. 1 , col. 2.

${ }^{1228}$ Id., April 6, 1960, p. 1, col. 8.

${ }^{123}$ Id., February 24, 1960, p. 36, col. 7 .

124 Id., February 26, 1960, p. 8, col. 3 .

${ }^{128}$ Id., February 28, 1960, p. 45, col. 4.

${ }^{120} \mathrm{Id}$., March 4, I960, p. Ir, col. I.

${ }^{127}$ Id., March 8, 1960, p. 21., col. 1 .
} 
Arlington, and elsewhere. ${ }^{128}$ There was no use of tear gas or fire hoses, although there were several isolated fist fights between demonstrators and white hecklers; and in Newport News, the officials patrolled the picket lines with police $\mathrm{K}_{9}$ corps dogs. ${ }^{129}$ As elsewhere, there were boycotts, although in Petersburg, the participants called it "a secession of Negro patronage."130 As in Memphis, Tennessee, Negroes were arrested and convicted for trespass in the public library. Fourteen Negroes, including three children, entered the Petersburg public library and went to the white section. When asked to leave, they refused and were arrested. Bonds were set at $\mathrm{I}, 000$ dollars each. ${ }^{131}$

In Suffolk, the Woolworth store opened its lunch counter on a service-to-all, stand-up basis. The counter was jammed with Negro patrons on the first day, but thereafter, their number declined sharply. ${ }^{132}$ **** *

"The determination that underlies the movement has been demonstrated from Alabama to Virginia," comments the New York Times. "Negroes have risked fines and jail sentences, attacks from angry whites and, in at least one case, possible death at the hands of a mob."132a

W.hat is behind the demonstrations? The New York Times suggests that "the militancy of the Southern Negro lies in a new-found belief that only through his own efforts can he achieve full citizenship status. There is frustration over the promise of democracy, made but never quite fulfilled. There is patience worn thin by years of fruitless waiting. There is the catalyst provided by the youths who refuse to accept a future limited by race rather than ability."133

What is the significance of the demonstrations? Minimally, again to quote the New York Times, they give the lie to two cherished beliefs: "The first is that the Southern white, and he alone, truly understands the Negro. The second depicts most Negroes as advocates of the practice that goes by the name of separate but equal.”134

What lies in the future? ${ }^{355}$ In many southern communities, the

${ }^{128}$ Durham (N.C.) Morning Herald, March 20, 1960, § A, p. 2, col. 6.

${ }^{120}$ Id., March 27, 1960, § C, p. 12, col. 2.

${ }^{130}$ N.Y. Times, March 22, 1960, p. 25, col. I.

${ }^{131} I d$., March 8, 1960, p. 21, col. I.

${ }^{132}$ Durham (N.C.) Morning Herald, March 20, Ig60, § A, p. 2, col. 7 .

${ }^{1328}$ N.Y. Times, March 13, I960, p. 6, col. 5.

${ }^{133}$ Ibid.

${ }^{134} I d$., March 6, 1960, p. 3, col. I.

${ }^{136}$ A Negro leader has put it this way: "The segregationists now face some hard alternatives: They can continue to seek to maintain segregated facilities. In this event they must live with discord or themselves initiate, and be responsible for, violence with 
mayors have appointed committees to "bridge the gap" between the races and attempt to achieve a solution to the problem. The Greensboro (North Carolina) Daily News praised the mayor of that community for appointing such a committee, and editorialized as follows: ${ }^{136}$

The lunch counter demonstrations do constitute a grave problem. Like Gandhi's passive resistance movement in India, they are growing. The white South's first impulse, like Great Britain's, is to slap them down hard. That might work if there were no justice on the sit-downers' side. But that is not the case. ...

The alternative, if nothing is done, is more commotion. Greensboro, where the trouble started, would be an excellent place to end it....

Greensboro, through its Mayor's Committee, has a chance to chart a practical and reasonable course for the South. It need not be all or nothing. It might be accommodation somewhere between. Without a plan avoiding two dangers there can only be more trouble for everybody.

A North Carolina judge suggests that "the key to this problem is to be found not in the law but in religion. The answer here depends upon which is the stronger-racial prejudice or love of one's neighbor. Both are strong in North Carolina today."136a

This writer is in agreement that the "key" to the problem is not to be found in the law. But, as in the school-segregation situations, the courts are under obligation to deal with the problems as brought before them, and the following pages are concerned with the legal issues of the demonstrations.

\section{II}

\section{The Legal Issues}

The events briefly highlighted above have given rise to the following types of legal problems: (I) Can participants in a boycott, or those who picket to bring about a boycott, be punished for violating antitrust

all its evil consequences. They may close the facilities as they have done in many places. But this will not end the movement; rather, it will spread to libraries, public parks, schools, and the like, and these too will have to be closed, thus depriviug both white and Negro of necessary cultural and recreational institutions. This would be a step backward for the whole of society. Or finally, they can accept the principle of equality. In this case they still have two alternative approaches. They may make the facilities equally bad for both white and Negro or equally good. Thus finally simply logic and justice in their own interests should direct them to the only acceptable solution-to accept equality and maintain it on the best level for both races." King, The Burning Truth In The South, The Progressive, May I960, p. Io.

${ }^{130}$ Greensboro (N.C.) Daily News, March 2I, I960, p. 4, col. I.

${ }^{136 a}$ Address by Special Judge J. Braxton Craveu, Jr., of the N. C. Superior Court 
or other laws designed to protect merchants from wrongful interference with their business opportunities? (2) Can the demonstrators, although the demonstrations are peaceful and orderly, be punished for breach of the peace or incitement to riot when the demonstrations are carried out in a volatile atmosphere where the slightest spark might provoke the white hecklers to violence? (3) Can student demonstrators be expelled from school because of participation in efforts to secure what they believe are their rights? (4) Can state trespass laws constitutionally be applied to demonstrators who invade the premises of dime stores against the direction of the store owners? These problems, in this context, are unique, untried, and unsettled. Answers cannot be given with certainty. However, it seems appropriate to define and delineate the problems, suggest some lines of inquiry and analogize the existing case law relevant to the discussion.

\section{A. Boycotts, Antitrust Laws, and Tortious Interference with Prospective Business Relations}

Nationally, ${ }^{137}$ regionally, ${ }^{138}$ and locally, ${ }^{130}$ the NAACP and other groups have called for a boycott or a "secession" of patronage of those stores which refuse to serve Negroes while seated. In Marshall, Texas, sixteen students were charged with "preventing commerce" when they sat down at an all-white lunch counter. ${ }^{140}$ In Nashville, Tennessee, eighty students were charged with conspiring to violate the state trade and commerce law by helping to direct lunch-counter demonstrations. ${ }^{141}$ In North Carolina, a judge suggested that the demonstrators might be punished under the common-law doctrine that makes it illegal to conspire to injure anyone's person, property or profession. ${ }^{142}$ How valid are these arrests and suggestions?

The federal antitrust laws make it illegal for anyone by way of contract, trust, conspiracy or otherwise to restrain interstate trade. ${ }^{143} \mathrm{~A}$ boycott, black-list, or concerted refusal to deal with the products of a

to the Morganton Pilot Club, Chapel Hill (N.C.) Weekly, April 28, x960, §B, p. 4, col. 3. The judge concluded in his speech that "no matter who stands there, the ground is said to be level at the foot of the Cross." Ibid.

${ }^{187}$ N.Y. Times, March 23, x960, p. 18, col. 3.

${ }^{138}$ Durham (N.C.) Morning Herald, March 15, 1960, § A, p. 2, col. 8.

${ }^{180}$ N.Y. Times, Feb. 24, x960, p. 36, col. 7 .

${ }^{140} I d$., April 4, 1960, p. 37, col. 2.

${ }^{141}$ Id., March 5, r960, p. xo, col. 2.

${ }_{142}$ Durham (N.C.) Morning Herald, April 5, 5960, § B, p. 8, col. 2.

${ }^{143}$ The Sherman Act $\S$ I, 26 Stat. 209 (1890), I5 U.S.C. \$ I (1958). 
business rival is an illegal restraint of trade under the federal antitrust laws. ${ }^{144}$ The Sherman and other antitrust acts, however, were designed to protect commercial competition and consequently prohibit only those restraints of trade imposed by competitors in the market place. Thus, the Supreme Court has held that a sit-down strike by a union is not illegal under the Sherman Act, even though the strike restrains the interstate movement of the employer's products, because "this effect on competition has not been considered to be the kind of curtailment of price competition prohibited by the Sherman Act."145

Many states have adopted laws similar to the federal antitrust statutes. ${ }^{146}$ Some states, including North Carolina, in addition, have specifically made boycotts illegal, but only when the target is a "business rival" and only when the purpose of the boycott is "to fix the price of value when the competition is removed."147 These state statutes have not been construed to deprive merchants or the public of the right to refuse to purchase goods from persons with whom they are not in direct economic competition. ${ }^{148}$ The existing judicial interpretations of the federal and state antitrust statutes, therefore, indicate that neither the dime-store demonstrators nor those who organize or participate in boycotts of the dime stores are violating the statutory laws relating to restraint of trade. ${ }^{149}$

\footnotetext{
${ }^{144}$ Associated Press v. United States, 326 U.S. I (x945); United States v. Women's Sportswear Manufacturers Ass'n, 336 U.S. 460 (1949).

${ }^{145}$ Apex Hosiery Co. v. Leader, 3 Io U.S. 469, 503-04 (1940).

${ }^{140}$ North Carolina statutes declare illegal "every contract, combination in the form of trust or otherwise, or conspiracy in restraint of trade or commerce." N.C. GEN. STAT. §75-I (1950). For similar state statutes see TENN. CODE ANN. §69-IOI (1955); Tex. Rev. Civ. Stat. AnN. art. 7426 (I95 I); VA. Code AnN. $\$$ 59-20 (1950).

${ }_{147}$ N.C. GEN. STAT. § 75-5(3) (1950).

${ }^{148}$ Rice v. Asheville Ice Company, 204 N.C. 768, x69 S.E. 707 (1933) (manufacturers of ice refused in concert to sell to a retailer); Lineberger v. Colonial Ice Co., 220 N.C. 444, I 7 S.E.2d 502 ( I94I) (same); Dallas Gen. Drivers v. Wamix, Inc., I56 Tex. 408, 295 S.W.2d 873 (1956) (it is not a conspiracy in restraint of trade for workmen to agree to strike and peacefully picket their employer). Cf. Association of Bailey v. Master Plumbers, 103 Tenn. 99, 52 S.W. 853 (1899) (bylaws requiring all members of a plumbers association to purchase only from designated dealers). The North Carolima court has gone so far as to sustain the legality of an agreement by cafe owners to boycott salesmen who sold products to a rival cafe owner. This agreement, said the court, "without any evidence of malice, fraud or coercion, did not give rise to the cause of action alleged." McNeill v. Hall, 220 N.C. 73, 16 S.E.2d 456 (r94 I).

${ }^{149}$ Quaere, do the store owners who meet and jointly decide to follow a policy of
} 
Apart from problems arising under the statutory laws as enacted by the legislatures, there are problems arising under the common law as developed by judges on a case-to-case basis. Conduct intended to interfere with prospective economic advantage and business opportunities may be an actionable tort for which the injured person may recover money damages. ${ }^{150}$ Liability usually turns upon the ultimate purpose or object which the defendant seeks to advance, and the legitimacy thereof. The decisions concerning picketing, black-lists, boycotts, and other forms of concerted economic pressure in other areas of social conduct indicate that the dime-store boycotters are not liable financially for any decrease in trade which might follow their actions.

Boycotts of the dime stores are not unlike the boycotts of movies that have gone on in the past years. The Legion of Decency, through the local clergy, urges all Roman Catholics to refrain from viewing movies that are morally offensive. Recent movies that were classified as morally offensive include The Moon Is Blue, The French Line, The Son of Sinbad, and Baby Doll. The Legion of Decency is not the only group that seeks the boycott of films offensive to the group it represents. The NAACP has often objected to showings of Birth of a Nation, which deals with the reconstruction period in the South. Jewish groups objected to the showing of Oliver Twist, members of the Ku Klux Klan picketed Island in the Sun, and the American Legion picketed Charlie Chaplin's Limelight so effectively in Jersey City that patrons could not

refusing sit-down service to Negroes violate the antitrust laws? The Sherman Act does not restrict "the long recognized right of trader or manufacturer engaged in an entirely private business, freely to exercise his own independent discretion as to parties with whom he will deal." United States v. Colgate \& Co., 250 U.S. 300, 307 (1919). The Sherman Act does, however, restrict the right of a merchant to reject customers when acting in concert with others. United States v. Parke, Davis \& Co., 362 U.S. 29 ( 1960 ). This does not resolve the issue, however, as the federal antitrust laws are only applicable if there is ( 1 ) an agreement or conspiracy (see Interstate Cir., Inc. v. United States, 306 U.S. 208 (1939) (unanimity of reaction to proposal jointly made sufficient to establish conspiracy)); (2) to restrain interstate trade (see Mandeville Island Farms, Inc. v. American Crystal Sugar Co., 334 U.S. 219 (1948) (restriction of sugar-beet acreage restricts interstate trade)); (3) to an extent "appreciable" (see United States v. Yellow Cab Co., 332 U.S. 2 I 8 (1947) (monopolizing replacements of 5,000 taxicabs violates Sherman Act)); (4) in the appropriate area of competition (see United States v. Paramount Pictures, Inc., 334 U.S. 13 3 (1948) (downtown theaters were an area of competition distinct from movie exhibition business generally)); Intarnational Boxing Club, Inc. v. United States, 358 U.S. 242 (1959) (promotion of championship boxing bouts was separate and distinct from business of promoting boxing bouts generally).

${ }^{150}$ Prosser, TORTS $\$ 107$ ( $2 \mathrm{~d}$ ed. 1955). 
get to the theater to purchase tickets. While the decisions are few, "picketing a theater while an objectionable motion picture is being shown ... seems designed primarily to warn others of an apprehended evil, and is unquestionably privileged .....151

Boycotts of the dime stores are not unlike the boycotts conducted by various citizens' groups to achieve ends and objectives deemed vital to them. The right of citizens to picket for the purpose of compelling store owners to cease exercising their lawful right of doing business on Sunday has been sustained, even though the picketing resulted in a substantial loss of business. ${ }^{152}$ Similarly, the right of citizens to picket with signs reading that the meat sold by the store was not Kosher has been upheld, despite a resulting loss of business. ${ }^{153}$ These and other cases hold that the right to picket peacefully, under the guaranty of free speech, extends to a dispute between a businessman and any citizen or group of citizens who may differ with him on a question of business policy. ${ }^{154}$

Labor unions traditionally use a variety of economic weapons to force employer compliance with their demands. These weapons include the boycott, ${ }^{155}$ the picket line, and the "Unfair" or "We Do Not Patronize" list. ${ }^{156}$ The early attitude of the courts toward the unions was that they were outlaw organizations, and their activities were criminal conspiracies to disrupt the social order. This point of view has long since given way to a recognition that unions are legitimate and socially desirable. ${ }^{157}$ Since 1940 , labor union picketing has been protected as an exercise of constitutional free speech ${ }^{\mathbf{1 5 8}}$ when carried on in a lawful

${ }^{151}$ Note, 7I HARv. L. Rev. 326, 366 (1957), citing Watch Tower Bible \& Tract Soc'y v. Dougherty, 337 Pa. 286, ix A.2d 147 (1940).

${ }_{252}$ Ex parte Lyons, 27 Cal. App. 2d 293, 8 I P.2d 190 (1938).

${ }^{253}$ Rosman v. United Strictly Kosher Butchers, 298 N.Y. Supp. 343 (Sup. Ct. 1937).

${ }^{206}$ Note, 37 CaLif. L. Rev. 296 (1949).

${ }^{165}$ SMITH, LABOR LAW 217 (1953).

${ }^{100}$ The NLRB has noted that "the unfair listing of a primary employer is a traditional weapon used by labor organizations in direct support of a primary labor dispute" and that it is designed to put pressure on the named employer "by diverse means, including withdrawal of services from him by union members..., refusal by such employees to accept his employment, product boycott by union employees and ... the public ...., sympathetic refusal by union employers to trade with him, and the disconcerting effect of widespread publicity of the labor dispute." Denver Bldg. \& Constr. Trades Council, 87 N.L.R.B. 755,756 (1949).

${ }^{257}$ PROSSER, TORTS 739 (2d ed. 1955).

${ }^{268}$ Thornhill v. Alabama, 3 10 U.S. 88 (1940). 
maniner ${ }^{150}$ and for lawful objectives. ${ }^{160}$ The "primary boycott" and use of "unfair lists" now go unchallenged. ${ }^{161}$

Picketing and boycott activities by Negro groups to end "Jim Crow" employment policies have been sustained on analogy to labor union picketing activity. The United States Supreme Court has noted that: ${ }^{102}$

The desire for fair and equitable conditions of employment on the part of persons of any race, color, or persuasion, and the removal of discriminations against them by reason of their race or religious beliefs is quite as important to those concerned as fairness and equity in terms and conditions of employment can be to trade or craft unions or any form of labor organization or association. Race discrimination by an employer may reasonably be deemed more unfair and less excusable than discrimination against workers on the ground of union affiliation.

The few state courts that have faced the problem are in agreement. A New York court refused to enjoin the picketing of a movie house by Negroes with the statement that: "The right of an individual or group of individuals to protest in a peaceable manner against injustice or oppression, actual or merely fancied, is one to be cherished and not to be proscribed in any well-ordered society."163

A Pennsylvania county judge, in a similar situation, said: "Unquestionably the respondents, or anyone else in fact, are privileged to request the management of a theater to employ a Negro machine operator and further they may lawfully urge the patrons of such a theater to do whatever they lawfully may to let the management know their feeling on the subject."164

The analogies above seem to afford tort immunity to the Negro dime-store demonstrators. (I) The self-interest of the Negro dimestore demonstrators in ending racial discrimination at the lunch counter is as great as that of those who picket and boycott movie houses in the hope of preventing others from viewing films deemed objectionable. ${ }^{165}$

${ }^{150}$ See, e.g., Milk Wagon Drivers Union v. Meadowmoor Dairies, Inc., 312 U.S. 287 (1941).

${ }_{100}^{10}$ See, e.g., Giboney v. Empire Storage \& Ice Co., 336 U.S. 490 (1949).

${ }^{101}$ Note, 62 YALE L.J. I I I I (1953).

${ }^{102}$ New Negro Alliance v. Sanitary Grocery Co., 303 U.S. 552, 56I (1938). The Court here reversed a federal court injunction against the picketing on the theory that a "labor dispute" existed between the parties within the meaning of the Norris-LaGuardia Act. See also Hughes v. Superior Court, 339 U.S. 460 (r950).

${ }_{103}$ Anora Amusement Corp. v. Doe, 12 N.Y.S.zd 400 (Sup. Ct. 1939).

${ }^{104}$ Stevens v. West Philadelphia Youth Civic League, 34 Pa. D. \& C. 612, 617 (County Ct. 1939).

${ }^{100}$ The degree of self, family, group, and public interest in the picketing is a factor 
(2) If there is any distinction between the Negro demonstrator's picketing and that of labor unions, it would seem that nonlabor picketing should have the preferred position. Labor unions are organized, disciplined, and possess economic and moral sanctions adequate to control their members, whereas the picketing by Negro students is substantially free of coercive aspects and remains the principal means by which they can communicate facts and ideas respecting important social issues. (3) The analogy between the two cases of racial picketing to end discriminatory employment practices and to end discriminatory service is self-evident.

\section{B. Breach of the Peace, Incitement to Riot, and the Right to Free Speech}

In Alabama, Negro students were threatened with arrest for breach of the peace when they asked for service in the courthouse snack shop, ${ }^{168}$ and thirty-two Negro students were convicted of disorderly conduct for participation in an on-campus mass protest rally. ${ }^{167}$ In Arkansas ${ }^{168}$ and in Florida, ${ }^{169}$ students were arrested for breach of the peace for refusing to leave store counters when requested, and in South Carolina for requesting service. ${ }^{170}$ Also in South Carolina, some 350 students were arrested for breach of the peace when they sought to conduct a protest prayer meeting on the courthouse steps. ${ }^{171}$ In Memphis, Tennessee, Negroes who entered a white library were arrested for disorderly conduct, ${ }^{172}$ and Negroes who entered the art gallery were arrested for loitering. ${ }^{173}$ These arrests raise a serious legal problem: Can persons espousing unpopular views be arrested because their activi-

in determining liability for interference with the prospective economic benefit of others. Prosser, TORTS 735 (2d ed. 1955).

${ }^{100}$ Text accompanying note 48 supra. The federal courts have held that courthouse cafeterias cannot discriminate against Negro patrons, even when leased to private entrepreneurs. Derrington v. Plummer, 240 F.2d 922 (5th Cir. 1956), cert. denied, 353 U.S. 924 (1957).

${ }^{107}$ See text accompanying note 54 supra. The right to peaceful demonstrations is well recognized. See, e.g., Hague v. Committee for Industrial Organization, 307 U.S. 496 (1939).

${ }^{108}$ See text accompanying note 59 supra. The legality of sit-ins is discussed below.

200 See text accompanying note 61 supra.

${ }^{170}$ See text accompanying note 104 supra.

${ }^{171}$ See text accompanying note ro5 supra.

${ }^{172}$ See text accompanying note I I4 supra. The federal courts have held that libraries receiving state money cannot discriminate against Negroes, even though the library is privately originated and privately managed. Kerr v. Enoch Pratt Free Library, 449 F.2d 212 (4th Cir. I945), cert. denied, 326 U.S. 721 (1945).

${ }^{173}$ See text accompanying note $x \times 5$ supra. 
ties, in and of themselves peaceful and orderly, arouse the resentment of others who thereby engage in lawless conduct? Five cases, two state and three federal, shed some light on this problem.

In People v. Burman, ${ }^{174}$ the defendants were convicted of a breach of the peace for marching through the city streets with red flags after notice that the display of such flags would cause riots. In upholding the convictions, the Michigan Supreme Court said this: "The question here is not whether the defendants have in general a right to parade with a red flag. It is this: Had they such right, when they knew that the natural and inevitable consequence was to create riot and disorder?" The court answered in the negative: "Their right to display a red flag was subordinate to the right of the public. They had no right to display it when the natural and inevitable consequence was to destroy the public peace and tranquillity."

Relying on the authority of the above Michigan decision, the North Carolina Supreme Court, in State v. Cole, ${ }^{175}$ affirmed the conviction of $\mathrm{Ku}$ Klux Klan leaders for inciting a riot by attempting to hold a meeting on a leased field in a neighborhood where their appearance aroused community opposition and hostility. The $\mathrm{Ku}$ Klux Klan "had been preaching racial dissension and hatred and conducting cross-burnings for the purpose of frightening certain Indian families in the community" of Robeson County. The announced meeting had received widespread publicity, and the Sheriff earlier had warned the Klansmen that there might be trouble. On the night in question, several Klansmen arrived carrying arms, and Indians, many armed, lined up across the road from the field where the meeting was scheduled. When the Klan spokesman arrived, he asked the Sheriff for protection, and the Sheriff replied that "if I had one hundred and fifty men, I couldn't keep the Indians of Robeson County from coming in on that field." The Sheriff did call for additional support, and nine deputies and about fifteen members of the Highway Patrol responded to his call. Before they arrived, however, several hundred shots were fired, and a news reporter and a soldier by-stander were slightly injured. The Klansmen were then arrested. Their conviction for inciting a riot was upheld, the court holding that the armed presence of the Klansmen "would be calculated to cause a breach of the peace ... in the community."

The United States Supreme Court has faced the problem of peaceful speech to a hostile audience on two recent occasions. Terminiello $v$.

${ }^{174}{ }_{54}$ Mich. 150,117 N.W. 589 (1908).

${ }^{75}$ State v. Cole, 249 N.C. 733 , ro7 S.E.2d 732 (1959), 38 N.C.L. REV. 274. 
Chicago ${ }^{178}$ sustained the value of unhampered discussion as against the value of public order. Terminiello gave a speech in a Chicago auditorium under the auspices of the Christian Veterans of America, an organization opposed to various racial minority groups. The meeting commanded considerable public attention, and a crowd of over a thousand persons gathered to protest. Terminiello was convicted under a city breach-of-the-peace ordinance that permitted punishment for speech that "stirred people to anger, invited public dispute, or brought about a condition of unrest." The Supreme Court reversed the conviction with the statement that: "[A] function of free speech under our system of government is to invite dispute. It may indeed best serve its high purpose when it induces a condition of unrest, creates dissatisfaction with conditions as they are, or even stirs people to anger."177

Within two years, however, the Supreme Court changed course in Feiner v. New York. ${ }^{178}$ A street-corner speaker gave the impression to a mixed audience that he was endeavoring to arouse the Negro people against the whites. The crowd was restless and there was some pushing, shoving, and milling around. A policeman "stepped in to prevent it from resulting in a fight" and asked the speaker to step down. The speaker refused, and was arrested for disorderly conduct. The Supreme Court sustained his subsequent conviction with these remarks: ${ }^{179}$

This Court respects, as it must, the interest of the community in maintaining peace and order on its streets. We cannot say that the preservation of that interest here encroaches on the constitutional rights of this petitioner.

We are well aware that the ordinary murmurings and objections of a hostile audience cannot be allowed to silence a speaker, and are also mindful of the possible danger of giving overzealous police officials complete discretion to break up otherwise lawful public meetings. . . . But we are not faced here with such a situation. It is one thing to say that the police cannot be used as an instrument for the suppression of unpopular views, and another to say that, when as here the speaker passes the bounds of argument or persuasion and undertakes incitement to riot, they are powerless to prevent a breach of the peace.

There is one final case that should be mentioned, Seller v. Johnson, ${ }^{180}$ as it demonstrates that the police must be vigilant peace officers for the unpopular speaker as well as for the hostile audience. The

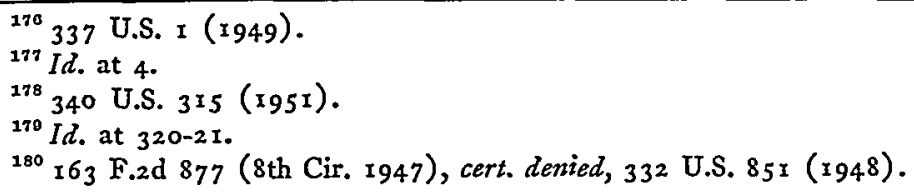


Jehovah's Witnesses in Iowa planned a series of four Sunday meetings in the Lacona city park. The speaker at the first meeting was harassed and interfered with, but succeeded in delivering his Bible lecture on "Religion as a Peacemaker." At the second meeting, there were numerous fist fights, with bloody faces, black eyes, broken glasses, and torn clothing. The Mayor prohibited the third meeting, and the Sheriff, with the assistance of about roo special deputies, blockaded the city against the Jehovah's Witnesses. The Witnesses then filed suit in the federal court under the Civil Rights Act of $187 \mathrm{I}^{181}$ to enjoin interference with their contemplated meeting. The requested relief was granted. The court pointed out that the roo persons deputized to blockade the highways could have been utilized to preserve order at the park and stated that: $:^{182}$

To secure the rights of free speech and assembly against abridgment, it is essential not to yield to threats of disorder. Otherwise these rights of the people to meet and of speakers to address the citizens so gathered, could not merely be abridged, but could be destroyed by the action of a small minority of persons hostile to the speaker or to the views he would be likely to express.

What do these cases mean when applied to the concrete situations that now exist because of the dime-store demonstrations? They mean that demonstrators who persist in picketing or mass-prayer meetings in the face of a riotous situation that the police cannot quell constitutionally can be convicted for breach of the peace and kindred crimes. This was the situation in the earliest days of the Chattanooga demonstrations, when the fire department was called upon to quell the mobs that at one time numbered in the thousands. These cases also mean that the police cannot use the pretext of an emergency situation to prohibit peaceful demonstrations. This seems to be the situation in Montgomery, where students were arrested for participation in an on-campus mass meeting, and in Memphis, where students were arrested for entering a public library and a public art museum. Somewhere in between these two extreme situations a line must be drawn that gives full recognition to both the constitutional rights of peaceful protest and the right of a city to maintain peace and order. In drawing this line, it is to be hoped that the courts will recognize that governmental units "can as a practical matter prevent violent interferences with speech if they wish. Suitable preventive and protective steps are most likely to be taken if the police

\footnotetext{
${ }^{181}$ REv. STAT. § 1979 ( 1875$)$, 42 U.S.C. $§ 1983$ (1958).

${ }^{182}{ }_{163} \mathrm{~F} .2 \mathrm{~d}$ at 881 quoting from Hague v. Committee for Industrial Organization, 307 U.S. 496,680 (1939) (amici curiae brief).
} 
are firmly told that a speaker cannot be charged with the crime of inciting a disturbance of the peace unless the police themselves have first done everything possible to protect the speechmaking."183

\section{School Expulsions and Off-Campus Political Activities}

Student demonstrators have been expelled from Alabama State College, from Southern University in Louisiana, and from Vanderbilt University in Tennessee. Expulsion from college ${ }^{184}$ is to many a far more serious sanction than the fines generally levied on those convicted under the trespass laws. ${ }^{185}$ These reprisals for student participation in offcampus political, social, and economic activities raise serious problems under the fourteenth amendment. ${ }^{186}$

The courts have jurisdiction by way of mandamus or otherwise to review the legality of school expulsions and will order reinstatement when the expulsion is made pursuant to regulations that are unreasonable, arbitrary, or discriminatory, or when the expulsion infringes upon some constitutional right. ${ }^{187}$ In applying this rule, courts have sustained

${ }^{183}$ Gellhorn, AMERICAN Rights 6i-62 (1960).

184 The Mississippi court recently held that a financially-able father can be compelled to provide college-education funds for his seventeen-year-old daughter, even though his divorced wife has the child's custody. The court remarked that the duty to provide a college education is a duty that the parent "not only owes to his child, but to the state as well, since the stability of our government must depend upon a well-equipped, a well-trained, and a well-educated citizenship." Pass v. Pass, i 18 So.2d 769, 773 (Miss. I960).

${ }^{185}$ The fine levied by the North Carolina courts for trespass in the Durham ice cream parlor was \$10.00. State v. Clyburn, 247 N.C. 455 , 101 S.E.2d 295 (1958). The fine levied by the Virginia courts for trespass in the Richmond bus terminal cafe was also \$10.00. N.Y. Times, Feb. 29, 1960, p. 18, col. 2. Of late, however, the fines are much more punitive. See text accompanying note 124 supra.

${ }^{180}$ Among the liberties guaranteed by the fourteenth amendment is "the right of the individual .... to acquire useful knowledge." Meyer v. Nebraska, 262 U.S. 390, 399 (1923). The state has no power to standardize its children, Pierce v. Society of Sisters, 268 U.S. 510, 535 (1925); or to compel uniformity of thought in the public schools. West Virginia State Bd. of Educ. v. Barnette, 319 U.S. 624, 642 (1943).

${ }^{287}$ The Legal Status of the Public School Pupil, 26 N.E.A. Research Bull. 28 (1948). A private educational institution is generally free to select whom it will admit as students, but once having admitted them, the institution cannot expel students except for reasons and by procedures set forth in its charter and catalogue. A Pennsylvania court held that it had no jurisdiction when suit was filed by an expelled student from a private college whose catalogue announced that it "reserves the right to exclude at any time students whose conduct or academic standing it regards as undesirable." Barker v. Trustees of Bryn Mawr College, $278 \mathrm{~Pa}$. 121, 122 Atl. 220 (1923). The New York courts, however, hold that a private institution cannot dismiss a student without reason or arbitrarily, even though the catalogue reserved to the institution "the right to require the withdrawal of any student at any time for any reason deemed sufficient to it." Anthony v. Syracuse Univ., 224 App. Div. 487, 23 I N.Y. Supp. 435 (1928). A Florida 
expulsions for violation of regulations banning the use of cosmetics and objectionable clothing, ${ }^{188}$ the smoking of cigarettes, ${ }^{180}$ the serving of liquor to other students, ${ }^{100}$ and marriage. ${ }^{191}$ These and similar regulations were deemed reasonably related to the maintenance of a proper atmosphere within the classroom or on the campus. ${ }^{102}$

A good deal of the "expulsion" litigation has concerned the reasonableness of regulations prohibiting membership in high school and col. lege fraternities. ${ }^{193}$ Most courts have held such regulations "not unreasonable, arbitrary or discriminatory and ... not vulnerable to any constitutional objection." 194 A Missouri court, on the other hand, held that the school had no right to prohibit pupils from participation in social activities outside of school hours unless the activities were detrimental to the operation and control of the school. Membership in fraternities was held to have no such effect. ${ }^{195}$

These cases point up a line drawn by the courts: "the teacher stands in loco parentis only within the sphere of his duty as a teacher"; the parent is responsible for disciplining because of off-campus, out-of-school misbehavior. These limits on the disciplinary authority of educational institutions were carved out in the landmark case of State ex rel. Clark v. Osborne, ${ }^{108}$ decided in 1887 . A school regulation prohibited attendance at social events without the permission of the school authorities. A sixteen-year-old girl student attended a party with the permission of her father, but without permission of the school. She was expelled and

court held that a student can recover damages from a private institution for "wanton and malicious expulsion." John B. Stetson Univ. v. Hunt, 88 Fla. 5 10, 102 So. 637 (1924). "It is uniformly held in the United States that the relation between a college and its students is a contractual one .... but in practice courts interfere only where there has been a palpable abuse of the wide discretion possessed by the authorities." Note, Right to Dismiss Student Without Stating Cause, 77 U. PA. L. REV. 694-95 (1929).

${ }_{188}$ Pugsley v. Sellmeyer, 158 Ark. 247, 250 S.W. 538 (1923).

${ }^{188}$ Tanton v. McKenney, 226 Mich. 245,197 N.W. 510 (1924).

${ }^{100}$ State v. Clapp, 81 Mont. 200, 263 Pac. 433, cert. denied, 277 U.S. 591 (r923).

${ }^{101}$ State v. Marion County Bd. of Educ., 202 Tenn. 29, 302 S.W.2d 57 (1959).

${ }^{102}$ It goes without saying that the courts have sustained expulsion for cheating on examinations, People v. Trustees of Univ. of Ill., ro Ill. App. 2d 207, 134 N.E.2d 635 (1956); for giving false testimony in a faculty investigation of a disciplinary disturbance, Goldstein v. New York Univ., 76 App. Div. 80, 78 N.Y. Supp. 739 (1902); and for creating a disturbance on the school bus. In re Neal, I64 N.Y.S.2d 549 (1957).

${ }^{103} \mathrm{~A}$ recent illustration of a regulation banning membership in fraternities whose constitutions discriminate on basis of race and religion is found in Webb v. State Univ. of N.Y., 125 F. Supp. 9 I0 (N.D.N.Y. I954), where the regulation was sustained.

${ }^{104}$ Burkitt v. School Dist. No. I, 195 Ore. 471, 246 P.2d 566 (1952). See generally The Legal Status of the Public School Pupil, 26 N.E.A. Research Bull. 28, 29 (1948). ${ }^{105}$ Wright v. Board of Educ., 295 Mo. 466, 246 S.W. 43 (1922).

${ }_{24}^{100}$ Mo. App. 309 (1887). 
brought a mandamus suit for reinstatement. The requested relief was granted, the court commenting that parents may either place their children under the control of other persons or leave them free to control themselves, and the choice is for the discretion of the parents. ${ }^{197}$

Despite the decisions that educational institutions can expel students only for activities that reasonably relate to the academic routine or for student conduct that infringes on school related affairs, there are three isolated decisions that sustain the right of the college (two of them private institutions) to expel because of off-campus behavior that reflects adversely on the institution. During World War I, the New York courts refused redress to a Columbia University student expelled for an off-campus antiwar speech in which he urged resistance to the draft. ${ }^{198}$ During the "cold war" following World War II, the Michigan court, without written opinion, refused redress to a student expelled for sponsoring an off-campus meeting at which an indicted Communist leader was the principal speaker. ${ }^{199}$ Just recently, the Florida court refused redress to a student expelled from the University of Miami School of Education for writing a letter to a newspaper in which he was "fanatical in his [favorable] views as to atheism."200 The above three situations have little in common with the current expulsions for participation in the dime-store demonstrations. Violation of trespass laws, for example, cannot fairly be equated with urging war-time resistence to the draft, conduct which the reviewing court deemed closely akin to treason. Much closer on point are the "flag salute" cases, for in each situation, the student claims a privilege to enforce a constitutional right, the exercise of which is made illegal by state law.

The flag salute requirement swept the country during World War I by state laws, state education department regulations, and local school board rules. West Virginia typically ${ }^{201}$ expelled students who refused to join in the flag salute and thereafter sent them to reformatories maintained for criminally-inclined juveniles. Parents of such children were prosecuted criminally for causing delinquency. ${ }^{202}$ In brief, refusal to salute the flag was a crime carrying with it the additional sanction of expulsion from school. This situation continued until members of the

${ }^{107}$ Elliott \& Chambers, The Colleges and the Courts 26 (1936).

${ }^{108}$ Samson v. Trustees of Columbia Univ., 167 N.Y. Supp. 202 (Sup. Ct. 1917).

${ }^{200}$ Zarichny v. State Bd. of Agriculture, 17 U.S.L. WeEK 3374, cert. den. 338 U.S. 816 (1949).

${ }^{200}$ Robinson v. University of Miami, 100 So. 2d 442 (Fla. Dist. Ct. App. 1958).

${ }^{201}$ For a general survey of the state statutes and decisions, see The Legal Status of the Public-School Pupil, 26 N.E.A. Research Bull. 28 (1948).

${ }^{202}$ West Va. State Bd. of Educ. v. Barnette, 319 U.S. 624, 629-30 (x943). 
Jehovah's Witnesses brought a suit to prevent the West Virginia State Board of Education from requiring their children to salute the flag. The Supreme Court put a halt to the expulsions. Pointing out that the fourteenth amendment protects students from school board action infringing on the Bill of Rights, here, freedom of religion, the Court said: "Free public education, if faithful to the ideal of secular instruction and political neutrality, will not be partisan or enemy of any class, creed, party, or faction." ${ }^{203}$

If the fourteenth amendment requires a "hands off" school board policy in a religious controversy, it requires a similar policy when students peacefully picket and demonstrate to achieve desired social objectives. Expulsion for participation in sit-ins makes the school authorities a forbidden "partisan or enemy" of a "class, creed, party, or faction," removes the student from the best influence of democracy, and distorts his sense of justice and faith in freedom. ${ }^{20.4}$ This is not good. As recently stated by the President of the Harvard University Board of Overseers, a university: $:^{205}$

is not and must not become an aggregation of like-minded people all behaving according to approved convention. It is a temple of the open-minded . . . the historical consequence of the mediaeval studium generale-a self-generated guild of students or of masters accepting as grounds for entrance and dismissal only criteria relevant to the performance of scholarly duties.

\section{Sit-Ins, Trespass Laws, and Unconstitutional State Action Under the Fourteenth Amendment}

Students have been arrested under state trespass laws for picketing on the privately-owned sidewalks of a Raleigh, North Carolina, privately-owned shopping center, ${ }^{206}$ for sit-ins in lunchrooms at the

${ }^{203} I d$. at 637 .

${ }^{204}$ Note, 29 NEB. L. REv. 485,501 (1950).

${ }^{205}$ Statement of Charles E. Wyzanski in support of proposition that "what faculty members do outside their posts, we should leave to outside authority." Harvard Alumni Bulletin, Jan. 23, 1956, p. 316.

Some forty years earlier, President Lowell, of Harvard, repudiated the concept of punishing a professor for off-campus extreme or injudicious actions with the statement that "if a university or college censors what its professors may say, if it restrains them from uttering something that it does not approve, it thereby assumes responsibility for that which it permits them to say. This is logical and inevitable but it is a responsibility which an institution of learning would be very unwise in assuming." 15 OFficial REGISTER OF HARVARD UNIVERSITY 19-20 (1916).

${ }^{200}$ On April 22, 1960, the trespass charges were dismissed by Superior Court Judge Jack Hooks on authority of Marsh v. Alabama, discussed at note 209 infra. District 
Atlanta, Georgia, Court House and City Hall, ${ }^{207}$ for sit-ins at the public library in Petersburg, Virginia, ${ }^{208}$ and for sit-ins at various privatelyowned dime stores throughout the South.

The Supreme Court has held that a state cannot constitutionally apply its trespass laws so as to punish a peaceful picketer for remaining on privately-owned sidewalks of a privately-owned town against the express orders of the town manager. ${ }^{209}$ The federal courts of appeals have held that states cannot discriminate against Negroes in libraries receiving public financial support, ${ }^{210}$ or in lunchrooms located in public buildings and under governmental control. ${ }^{211} \mathrm{It}$, therefore, seems clear that the states cannot punish Negroes for entering an establishment where the state cannot prohibit their presence. ${ }^{212}$ Less clear-indeed, highly uncertain - is the right of a state to apply its trespass laws against Negroes who remain in a privately-operated dime store after being told to leave. The law on this point is open. In 1958, the North Carolina Supreme Court in State v. Clyburn ${ }^{213}$ sustained a trespass conviction against Negroes who refused to leave a Durham ice cream parlor when so directed, but the litigants did not raise and the court did not pass upon the contention that the "judicial" enforcement of the trespass laws was state action forbidden by the fourteenth amendment. The

Solicitor L. V. Chalmers, Jr., supported the defense motion for a nonsuit and said he had talked to Attorney General Wade Bruton about the cases and was told that the Attorney General might concede error if the cases were to reach the State Supreme Court. Raleigh (N.C.) News \& Observer, April 23, 1960, p. I, col. I.

${ }^{207}$ See text accompanying note 74 supra.

${ }^{208}$ See text accompanying note ${ }^{3} \mathrm{I}$ supra.

${ }^{200}$ Marsh v. Alabama, 326 U.S. 501 (1946). "The 'business block' serves as the community shopping center and is freely accessible and open to the people in the area and those passing through. The managers appointed by the corporation cannot curtail the liberty of press and religion of these people consistently with the purposes of the Constitutional guarantees, and a state statute, as the one here involved, which enforces such action by criminally punishing those who attempt to distribute religious literature clearly violates the First and Fourteenth Amendments to the Constitution." Id. at 508 .

${ }^{310}$ Kerr v. Enoch Pratt Free Library, 149 F.2d 212 (4th Cir. 1945), cert. denied, 326 U.S. 721 (1945).

${ }^{212}$ Derrington v. Plummer, 240 F.2d 922 (5th Cir., cert. denied, 353 U.S. 924 (1957).

${ }_{213}$ State v. Cooke, 248 N.C. 485,103 S.E.2d 846 (1958). Here, Negroes were convicted for unlawful entry upon a golf course, despite a prior federal court order enjoining racial discrimination. The North Carolina Supreme Court recognized that "if a party entering upon the land has a legal right to do so, of course he may not be convicted of a trespass," but sustained the trespass conviction because the defendants had failed to put the federal court order (which was not a proper subject for judicial notice) into the record.

${ }^{213} 247$ N.C. 455 , ror S.E.2d 295 (1958). The Negro litigants had to show unconstitutional "state" action and put primary reliance on a city ordinance requiring 
issue not having been raised or passed upon, the decision does not constitute a precedent when the question is finally brought to the fore. ${ }^{214}$ The issue was raised in a subsequent Virginia bus terminal trespass case, and the Supreme Court has agreed to hear an appeal from the Virginia Court's affirmance of conviction. ${ }^{215}$ As the Supreme Court may well dispose of the case without reaching the issue under discussion, ${ }^{210}$ it is appropriate to sketch the competing interests and outline the analogies that might prove helpful in balancing them.

Historically, apart from "innkeepers," "public carriers," and the like, ${ }^{217}$ the proprietor of a business can deal with his patrons as he likes-

segregation in restaurants. This would have been sufficient, but the litigants failed to put the ordinance into evidence, and the courts, consistent with prior holdings, refused to take judicial notice of its existence. The litigants additionally sought to prove "state" action because ( 1 ) the ice cream parlor was licensed and periodically inspected by health officials, and because (2) they had been arrested by a city policeman. The North Carolina courts, consistent with the decisions in other jurisdictions, held that the mere fact that an establishment is subject to state control through health and sanitation inspection is not sufficient to make the establishment an agent of the state for purposes of the fourteenth amendment. The North Carolina courts further held that the arrest by a policeman is not "state" action. This is contrary to the rulings of many courts, both state and federal. See text accompanying note 243 infra.

${ }^{214}$ King Mfg. Co. v. Augusta, 277 U.S. roo, 135 (1928); United States v. More, 7 U.S. (3 Cranch) 159, 172 (1805).

${ }^{215}$ Bruce Boynton, a Negro student at Howard University in Washington, D.C., went south on a bus. The bus stopped for a forty-minute layover at a terminal in Richmond. Boynton went into the restaurant for Negroes, which was crowded, and then into the "white" restaurant. He was refused service and told to leave. When he refused, he was arrested and convicted of trespass. The Virginia Supreme Court of Appeals affirmed the $\$ 10.00$ fine without opinion. The United States Supreme Court granted the petition for review that raised two contentions: first, that when the private restaurant chose to invoke the power of the state by having Boynton prosecuted, the discrimination against him became official, not private, and hence violated the fourteenth amendment; second, segregation of terminal restaurants put an undue burden on interstate commerce. Boynton v. Virginia, 36r U.S. 958 (1960); N.Y. Times, Feb. 24, 1960, p. 29, col. 6.

${ }_{318}$ The Court might analogize bus terminal cafes to railroad dining cars and thereby hold the discrimination illegal under the Interstate Commerce Act. Henderson v. United States, 339 U.S. 816 ( $\left.195^{\circ}\right)$. This would be in keepiug with the Court's practice, when faced with two alternative grounds for decision, to make its ruling on the basis of statutory construction, which can be changed by Congress through the amendatory process, rather than on the basis of the Constitution. Thus, if the Court conforms to prior practice, it will not reach the constitutional issues unless it first rules that a bus terminal cafe is not an "instrumentality" of commerce within the scope of the Interstate Commerce Act.

${ }^{217}$ The common law imposed upon innkeepers, common carriers, wharfingers, and others who operated businesses having the nature of a public utility the obligation to serve all well-behaved customers without discrimination. In England, rejection of a guest was long ago made a crime and remediable by suit for damages. The rule is viable there today, as witnessed by a recent case in which a renowned West Indian Negro cricketer recovered against a British hotel for refusal to serve him. Constantine v. 
denying service to some and not to others. This right to deny service was recognized by the English common law ${ }^{218}$ and some fifty years ago by the United States Supreme Court. ${ }^{219}$ Such is the law except in the twenty-six states that recently enacted laws prohibiting such discrimination. ${ }^{20}$ Recent illustrations are found in Williams v. Howard John son's Restaurant, ${ }^{221}$ where the Court of Appeals for the Fourth Circuit refused a Negro's request to order a restaurant to serve him; and Eaton v. Board of Managers of James Walker Memorial Hospital, 222 where the same court refused a Negro doctor's request to order a hospital to allow him admission so that he could treat his patients.

Clashing with the right of the private proprietor to refuse service

Imperial Hotels, Ltd., I K.B. 693, 2 All E.R. I7x (1944).

The obligation to serve all comers is due to the public nature of the business, 28 AM. Jur. Innkeepers 565 (1959), the need to protect the traveler in a day when the solitary inn between cities was a necessity on long, dangerous jonrneys, and the unfairness in permitting an innkeeper to pick and choose when he "allured travelers to his tavern by holding himself out to the pnblic as ready to entertain them." State v. Steele, 106 N.C. 766 , is S.E. $47^{8}$ (1890).

The various states are free to accept or reject this common-law doctrine. Delaware, Mississippi, Tennessee, and Florida have rejected it. GREENBERg, RACE RELATIONs AND AMERICAN LAW 97 (1959). North Carolina has accepted it with the modification that innkeepers are not required to accept guests "so objectionable to the patrons of the house, on account of the race to which they belong, that it would injure the business to admit them to all portions of the house." State v. Steele, supra at 782 , II S.E, at 484 . This case was subsequently construed as holding that "innkeepers may assign them [white and colored guests] separate apartments, provided they furnish equal accommodatious to both.” McMillan v. School Comm., 107 N.C. 609, 614, 12 S.E. 330,331 (1890).

The common-law obligation extended to hotel restaurants, but in Virginia, such establishments need not serve casual Negro patrons. Alpaugh v. Wolverton, $184 \mathrm{Va}$. 943, 36 S.E.2d 906 (1946). See Note, Racial Discrimination by Restaurant, 46 VA. L. REv. 123, 124 (1960).

${ }^{218}$ Wood v. Leadbitter, ${ }_{3}$ M. \& W. 838,153 Eng. Rep. $35^{1}$ (1845). Here, the English Court of the Exchequer ruled that tickets for admission to a race track were revocable at any time without return of the money paid and without assignment by the owner of any reason for the revocation.

${ }^{210}$ Marrone v. Washington Jockey Club, 227 U.S. 633 ( $19 \times 3$ ). The Court, in an opinion by Mr. Justice Holmes, held that a patron ejected from a race track with no more force than necessary did not have a cause of action in trespass, assault, or false arrest.

A few jurisdictions now allow recovery for wrongful rejection in the absence of statute. The Louisiana Supreme Court recently gave $\$ 250$ in damages for humiliation and embarrassment to a ticket holder ejected from a theater because he was a cripple, Vogel v. Saenger Theatres, 207 La. 835, 22 So. $2 \mathrm{~d}$ I89 (r945); and a federal court allowed recovery to a Negro when a hotel refused to honor his mail reservation, Thomas v. Pick Hotels, 224 F.2d 664 (1oth Cir. 1955).

${ }^{220}$ See Greenberg, Race Relations and american Law yor (1959); Emerson \& Haber, Political and Civil Rights in the United States 14i3 (2d ed. 1958).

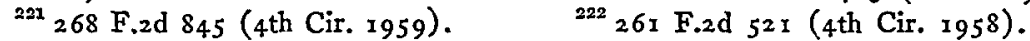


to patrons deemed undesirable is the right of all persons, Negroes included, to acquire property. This right to "acquire and possess property of every kind" is "fundamental to citizenship" and as such is guaranteed by the privileges and immunities clause of the Constitution. ${ }^{223}$ It is guaranteed against federal and state infringement by the due process clauses of the Constitution. ${ }^{224}$ It is guaranteed by a federal statute ${ }^{225}$ now incorporated into the equal protection clause of the fourteenth amendment. ${ }^{226}$

This fundamental right of equality in opportunity to acquire property and the fruits of a civilized society has been deemed paramount to the right of governments to district city housing on racial lines; ${ }^{227}$ to the right of state ${ }^{228}$ and federal ${ }^{229}$ courts to enforce restrictive covenants in real estate contracts; and to the right of state and city instrumentalities to enforce segregation in city buses, ${ }^{230}$ city libraries, ${ }^{231}$ public auditoriums, ${ }^{232}$ athletic events, ${ }^{233}$ swimming pools, ${ }^{234}$ beaches, ${ }^{235}$ golf

${ }^{223}$ Corfield v. Coryell, 4 Wash. C.C. 371 ( 1823 ) (a case arising under the privileges and immunities clause of art. IV, $\S_{2}$ of the Constitution), quoted with approval in the Slaughter-House Cases, 83 U.S. ( 16 Wall.) $36,75-76$ (1873) (a case arising under the privileges and immunities clause of the fourteenth amendment).

224 Oyama v. California, 332 U.S. 633 (1948), holding unconstitutional the California Alien Land Law prohibiting Japanese from acquiring agricultural land.

${ }^{225}$ Discussed at note 2 supra.

${ }^{226}$ Hurd v. Hodge, 334 U.S. 24 (1948). "If there is any one purpose of the Fourteenth Amendment that is wholly outside the realm of doubt, it is that the Amendment was designed to bar States from denying to some groups, on account of their race or color, any rights, privileges, and opportunities accorded to other groups." Oyama v. California, 332 U.S. 633, 649 (1948) (Black, J., concurring).

${ }^{227}$ Buchanan v. Warley, 245 U.S. 60 (1917) (city ordinance districting city on racial lines to prevent race riots declared unconstitutional in suit brought by willing white vendor to enforce contract of sale with Negro purchaser); City of Richmond v. Deans, 281 U.S. 704 (1930) (city ordinance districting city on racial lines to prevent interracial marriage declared unconstitutional in suit brought by Negro who sought freedom to seck opportunity to purchase a house in white ncighborhood).

${ }^{228}$ Shelley v. Kraemer, 334 U.S. I (r948).

${ }^{229}$ Hurd v. Hodge, 334 U.S. 24 (I948).

${ }^{230}$ Browder v. Gayle, 142 F. Supp. 707 (E.D. Ala.), aff'd per curiam, 352 U.S. 903 (1956); Flemming v. South Carolina Elec. \& Gas Co., 224 F.2d 752 (4th Cir. 1955), appeal dismissed, 35 I U.S. $90 x$ (1956).

${ }^{231}$ Kerr v. Enoch Pratt Free Library, 149 F.2d 212 (4th Cir.), cert. denied, 326 U.S. 72 I (1945).

${ }^{232}$ Commonwealth v. Taylor, 3 R.R.L.R. $3 \times 3$ (Arlington, Va., Cir. Ct. 1958).

${ }^{233}$ Dorsey v. State Athletic Comm'n, I68 F. Supp. 149 (E.D. La. I958), aff'd, 359 U.S. 533 (1959).

${ }^{234}$ Lonesome v. Maxwell, 220 F.2d 386 (4th Cir.), aff'd sub nom. Mayor of Baltimore City v. Dawson, 350 U.S. 877 (I955).

${ }^{235}$ Tate v. Department of Conservation, 231 F.2d 615 (4th Cir.), cert. denied, 352 U.S. $8_{3} 8(1956)$. 
courses, ${ }^{236}$ public housing, ${ }^{237}$ the sale of liquor, ${ }^{238}$ the sale of groceries, ${ }^{239}$ and the sale of food at a courthouse cafe. ${ }^{240}$

This fundamental right to equality of opportunity in acquiring property of every kind is said to be free only from "state" interference, not from "private" discriminatory practices. This is the result of the landmark Civil Rights Cases ${ }^{241}$ of 1883 . There, theater owners, innkeepers, and the management of a railroad were indicted under the Civil Rights Act of 1875 , which made it a federal crime for the owner of public conveyances, theaters, and other places of public amusement to deny anyone the full and equal enjoyment of their accommodations. The defendants had denied access to Negroes because of their race. The Supreme Court dismissed the indictments on the ground that the Civil Rights Act there in issue was beyond the constitutional authority granted Congress by the thirteenth and fourteenth amendments. The Court held that these amendments were not intended to end discrimination by private persons, but only to "provide modes of redress against the operation of state laws, and the action of state officials executive or judicial."242

${ }^{230}$ Holmes v. City of Atlanta, 350 U.S. 879 (1955).

${ }^{337}$ Detroit Housing Comm'r v. Lewis, 226 F.2d 180 (6th Cir. 1955).

${ }^{238} \mathrm{De}$ Angelis v. Board of Liquor License Comm'rs, I R.R.L.R. 370 (Baltimore, Md., City Ct. 1955) (unconstitutional for the Baltimore Board of Liquor Commissioners to grant liquor licenses for colored or white patronage only, but not both).

${ }_{230}$ People v. Moore, 50 Hun. 356, 3 N.Y. Supp. 159 (1888). Here, a mining company directed an employee named Moore to keep various tradesmen out of the privately-owned city where the company employees lived. Moore turned away a tradesman named Snyder, and consequently was charged with assault and battery. The defense raised was that Snyder was a trespasser. The New York court said this: "We assume that if Snyder was a trespasser, the assault was justifiable, for no more force was used than was reasonably necessary to eject him from the premises. But he was not a trespasser. The streets leading to and about this village were made and opened by the Burden Iron \& Ore Company for such public use as was incident to the wants, convenience, and happiness of the people residing there. To the extent of this public use the company subjected its private property to the law which regulates public rights. . . By reserving the legal title to the thoroughfares of its village, it does not reserve autocratic powers over the people residing along them. To prevent the members of its community from buying supplies of Snyder, or of any tradesman not nominated by the company, would be to introduce a badge of vassalage inconsistent with our free institutions. If these families may buy of Snyder, then he may deliver his wares to them, and use for the purpose the appropriate thoroughfares. The assault was therefore not justifiable." People v. Moore, 3 N.Y. Supp. at 161 .

${ }^{240}$ Derrington v. Plummer, 240 F.2d 922 (5th Cir. 1956), cert. denied, 353 U.S. 924 (1957).

241 109 U.S. 3 ( 1883 ).

242 109 U.S. at 17 . The Court in the Civil Rights Cases dealt with a statute enacted pursuant to the thirteenth and fourteenth amendments. It reserved for future litigation the question of whether Congress could prohibit racial discrimination by private indi- 
It follows that a private store owner acting alone can discriminate against Negro customers without violating the fourteenth amendment. A problem arises only when the store owner calls a policeman or otherwise invokes the aid of the state judicial process in enforcing his privately. originated discriminatory schemes.

The actions of the police ${ }^{243}$ and of licensed private detectives ${ }^{244}$ are the actions of the state for purposes of the fourteenth amendment, even when the police act contrary to the state law. ${ }^{245}$ A United States Court of Appeals held that a policeman acts under "color of law" when he ejects a Negro from a privately-owned amusement park swimming pool at the request of the proprietor and thereby subjects himself to suit for injunctive, declaratory, and monetary relief for denying the Negro ticket-holder the right to make and enforce contracts. Moreover, the proprietor who called the policeman is also subject to suit for his participation in the denial of constitutional rights. ${ }^{246}$ Another federal court enjoined motion picture theater owners and two local police officials from enforcing racially-segregated seating in the theater. The court ruled that the practice instituted by the owners and aided by the police violated the Federal Civil Rights Act in that all defendants deprived Negro patrons of fundamental liberties under "color of law."

The actions of a judge, like the actions of a policeman, are the actions of the state for purposes of the fourteenth amendment. This was first

viduals under some constitutional power other than these amendments. The authority of Congress under the power granted it by the interstate commerce clause to prohibit discrimination by private owners of transport facilities is now established (see, e.g., Henderson v. United States, 339 U.S. 816 (1950)), as is the authority of Congress under the power granted it to regulate the District of Columbia to prohibit discrimination by private owners of eating establishments (see, e.g., John R. Thompson Co. v. District of Columbia, 346 U.S. 1oo (1953)).

${ }^{243}$ Screws v. United States, 325 U.S. 91 (1945).

24 Williams v. United States, 34 I U.S. 97 (1951).

${ }^{265}$ When a policeman fails to act in a situation requiring action, his failure to perform his duty is illegal "state" action that gives the federal courts jurisdiction over a suit against him. Catlette v. United States, 132 F.2d 902 (4th Cir. 1943). In this case, a deputy sheriff was indicted for "willfully" subjecting a person to the deprivation of rights secured or protected by the Constitution. Catlette had stood by while a group of American Legionnaires forced Jehovah's Witnesses to consume large quantities of castor oil. The court said: "Since the failure of Catlette to protect the victims from group violence or to arrest the members of the mob who assaulted the victims constituted a violation of his common law duty, his dereliction in this respect comes squarely within the provisions of 18 U.S.C.A. sec. 52 [the Civil Rights Act]." 132 F.2d at 907.

${ }^{246}$ Valle v. Stengel, 176 F.2d 697 (3d Cir. 1949). See Note, Freedom To Contract, A New Civil Right, 59 Yale L.J. II67 (1950).

${ }^{247}$ Manning v. Crowl (E.D. Pa., No. 10946, 1953), discussed in EMERson \& Haber, Political and Civil Rights in the United States 3415 (2d ed. i958). 
decided in 1879 when the Supreme Court held that a state judge who denied Negroes the right to serve as jurors unconstitutionally violated rights guaranteed by the fourteenth amendment. The Court said this: 248

A state acts by its legislative, its executive, or its judicial authorities. It can act in no other way.... Whoever, by virtue of public position under a state government denies or takes away the equal protection of the laws, violates the constitutional inhibition; and as he acts in the name of and for the state, and is clothed with the state's power, his act is that of the state. This must be so, or the constitutional prohibition has no meaning. Then the state has clothed one of its agents with power to annul or to evade it.

Since that time, the Supreme Court has ruled that a state unconstitutionally infringes upon liberties of speech and religion when a state judge convicts a Jehovah's Witness for inciting breach of the peace by playing an anti-Catholic phonograph record on the streets of a Catholic neighborhood; ${ }^{249}$ that a state unconstitutionally infringes rights of free speech when a state judge convicts a leaflet distributor under the state trespass law for remaining on privately-owned sidewalks when told by the owner to leave; ${ }^{250}$ that a state unconstitutionally infringes on freedom of speech when a state judge enjoins "stranger picketing" under a common-law policy banning all picketing unless done by the employer's own employees; ${ }^{251}$ that a state unduly infringes upon the right of communication when a state judge jails a litigant for contempt of court by publishing remarks hostile to the judge; ${ }^{252}$ and that state ${ }^{253}$ and federal judges ${ }^{254}$ unconstitutionally interfere with the right of Negroes to acquire property when they enforce the provisions of racial restrictive covenants in real estate deeds. "That the action of state courts and judicial officers in their official capacities is to be regarded as action of the state within the meaning of the Fourteenth Amendment is a proposition which has long been established by decisions of this court."255

Recently, the Supreme Court has held that a state court cannot award damages against a white vendor who violates the terms of a restrictive covenant, because so doing would devitalize the constitutional

\footnotetext{
${ }^{288}$ Ex parte Virginia, Ioo U.S. 339,347 (1879).

${ }^{20}$ Cantwell v. Connecticnt, 3 ro U.S. 296 (r940).

${ }^{250}$ Marsh v. Alabama, 326 U.S. 5or (r946).

${ }^{201}$ AFL v. Swing, 312 U.S. 321 (194r).

252 Bridges v. California, $3 x_{4}$ U.S. 252 ( $194 \mathrm{r}$ ).

${ }^{253}$ Hurd v. Hodge, 334 U.S. 24 ( 1948 ).

${ }^{20 t}$ Shelley v. Kraemer, 334 U.S. I (1948).

${ }^{250}$ Id. at $\mathrm{r} 4$.
} 
right of a Negro purchaser, ${ }^{256}$ and has questioned but not passed upon the right of a state court to hear a defense involving private racial discrimination. ${ }^{257}$ Similarly, the Court has questioned but not decided the issue of whether judicial recognition and enforcement of a collectivebargaining contract, under which an employee was discharged for alleged Communist activities, was state action in the sense that fourteenth amendment restraints come into play. ${ }^{258}$ But whatever the outer reaches of the doctrine may be, it is clear that judicial enforcement of the state trespass laws is state action within the scope and meaning of the fourteenth amendment. This, however, merely leads to the problem, for it is not all "state action" that is unconstitutional. Is this particular state action-i.e., judicial enforcement of state trespass laws at request of dime store operators-unconstitutional?

It is no answer to say that dime stores are privately owned and operated and, therefore, the proprietors have a right to do as they please with their own businesses. The state has an obvious interest in every business serving the public, and under certain conditions, it can, if it wishes, enact statutes that regulate a host of items, including the wages paid employees, ${ }^{250}$ the health and sanitary conditions, ${ }^{260}$ the prices charged the customers, ${ }^{201}$ the items which can or cannot be sold, ${ }^{202}$ and even the right of the proprietor to refuse service to a given class of would-be customers. ${ }^{263}$ "All rights tend to declare themselves absolute in their logical extreme. Yet all in fact are limited by the neighborhood of principles of policy which are other than those on which the particu-

${ }^{258}$ Barrow v. Jackson, 346 U.S. 249 (1953).

${ }^{25 z}$ Rice v. Sioux City Memorial Park Cemetery, 349 U.S. 70 (1955). Mrs. Rice, a Caucasian, purchased a burial lot when her Indian husband was killed fighting in Korea. Services were conducted at the grave site, but after the burial party had disbanded, the cemetery refused to bury the husband. The wife sued for damages, and the cemetery defended on a clause in the burial lot contract of sale reciting that "burial privileges accrue only to members of the Caucasian race." The wife moved to strike this defense, contending that judicial recognition of such a clause was unconstitutional state action. The trial court recognized the defense, and this was affirmed by the Iowa Supreme Court. The United States Supreme Court heard the case and affirmed by evenly divided vote. The Supreme Court then agreed to hear the case again, but after argument discovered that the Iowa legislature had outlawed such clauses after this incident, and therefore dismissed the case as no longer raising "special and important" questions.

${ }^{258}$ Black v. Cutter Labs., 35I U.S. 292 (1956).

${ }^{250}$ West Coast Hotel Co. v. Parrish, 300 U.S. 379 (1937).

${ }^{280}$ Adams v. Milwaukee, 228 U.S. 572 (I913).

${ }^{201}$ Nebbia v. New York, 291 U.S. 502 (1934).

${ }^{262}$ Williamson v. Lee Optical Co., 348 U.S. 483 (1955).

${ }^{203}$ California State Auto Ass'n Inter-Ins. Bureau v. Maloney, 341 U.S. ro5 (1951) (poor imsurance risks); Bob-Lo Excursion Co. v. Michigan, 333 U.S. 28 (1948) (Negroes). 
lar right is founded and which become strong enough to hold their own when a certain point is reached." A few analogies make this clear.

Private employers, as a general proposition, have freedom to hire and fire whom they will. But when the congressionally granted right of employees to engage in free self-organization comes into play, it becomes an enjoinable offense for an employer to fire a worker because of his prounion activities. ${ }^{265}$ In like vein, the owners of private businesses, again as a general proposition, can bar trespassers from entering their premises. But when the right of self-organization comes into play, it sometimes becomes an enjoinable offence for employers to prohibit the entrance of union organizers to distribute union handbills on company-owned parking lots, on the company-owned sidewalks leading to the street, or in the company-owned restaurants. ${ }^{266}$ In one unusual situation, the owner of a retail store was ordered to make his business premises available for a union mass meeting during working hours and on paid-time. ${ }^{267}$ It is all a question of balancing conflicting societal interests in the light of the facts of the given situation. As stated by the Supreme Court: $:^{268}$

Organization rights are granted to workers by the same authority, the National Government, that preserves property rights. Accommodations between the two must be obtained with as little destruction of one as is consistent with the maintenance of the other. The employer may not affirmatively interfere with organization; the union may not always insist that the employer aid organization. But when the inaccessibility of employees makes ineffective the reasonable attempts by nonemployees to communicate with them through the usual channels, the right to exclude from property has been required to yield to the extent needed to permit communication of information on the right to organize.

In applying this "ease of communication" test, companies whose employees come from many directions and far quarters are required to open their premises to union organizers, whereas companies whose employees are centrally-located in a nearby community can enforce "nosolicitation" and "no-trespass" rules. ${ }^{269}$

\footnotetext{
${ }^{204}$ The words are those of Mr. Justice Holmes in Hudson County Water Co. v. McCarter, 209 U.S. 349, 355 (1908).

${ }_{205}$ NLRB v. Jones \& Laughlin Steel Corp., 301 U.S. I (1937).

${ }^{206}$ Republic Aviation Corp. v. NLRB, 324 U.S. 793 (1945).

${ }_{207}$ Bonwit Teller, Inc. v. NLRB, I97 F.2d 640 (2d Cir. 1952), cert. denied, 345

U.S. 905 (1953).

$=08$ NLRB v. Babcock \& Wilcox Co., 35I U.S. 105, 112 (1956).

${ }^{200}$ Compare Republic Aviation Corp. v. NLRB, 324 U.S. 793 (1945), with NLRB

v. Babcock \& Wilcox Co., 35 I U.S. I05 (1956).
} 
Just as the rights of private proprietorship to exclude undesirables must sometimes yield to the right of employees to form unions of their own choosing, so also the rights of private proprietorship to exclude undesirables from their property must sometimes yield to the interest of free speech and religion. Marsh v. Alabama ${ }^{270}$ concerned a Jehovah's witness who was arrested under the Alabama trespass law when she refused the order of the town manager to cease distribution of religious literature on the privately-owned sidewalks of the business district of the company-owned town of Chickasaw. The Supreme Court held that the arrest unconstitutionally infringed on rights of free speech and religion and said this: ${ }^{271}$

We do not agree that the corporation's property interests settle the question. The State urges in effect that the corporation's right to control the inhabitants of Chickasaw is coextensive with the right of a homeowner to regulate the conduct of his guests. We cannot accept that contention. Ownership does not always mean absolute dominion. The more an owner, for his advantage, opens up his property for use by the public in general, the more do his rights become circumscribed by the statutory and constitutional rights of those who use it.

This "open up his property for use by the public in general" test has been applied subsequently in several contexts. The Virginia courts have sustained the constitutionality of trespass laws as applied to Jehovah's Witnesses who distributed leaflets in the upper corridors of an exclusive apartment house over the protest of the lobby attendant and the apartment manager. ${ }^{272}$ The New York courts have sustained the right of one who owns I 7 I adjoining and interrelated apartment houses to forbid Jehovah's Witnesses access to the inner hallways, but not the private streets, lanes, and parks within the housing development. ${ }^{273}$ The Texas courts issued an injunction against Jehovah's Witnesses' use of a park owned by a company as the undisputed state of the record showed that the company intended to "maintain these premises for the social and recreational use only of itself, its departments, and employees."274 The Massachusetts courts have held that the state trespass

${ }^{270} 326$ U.S. 501 (1946).

271 Id. at 505-06.

${ }^{272}$ Hall v. Commonwealth, 188 Va. 72, 49 S.E.2d 369, appeal dismissed for lack of substance in question presented, 335 U.S. 875 (1948).

${ }^{273}$ Watchtower Bible \& Tract Soc'y v. Metropolitan Life Ins. Co., 297 N.Y. 339, 79 N.E.2d 433 (1948).

${ }^{274}$ Good v. Dow Chemical Co., 247 S.W.2d 608 (Tex. Civ. App. I952). 
law cannot lawfully be applied to a Jehovah's Witness who rings the bells in the vestibule of an apartment house against the orders of the owner as "an implied license was granted to the defendants and all others engaged in lawful pursuits to make use of them for the purpose of seeking an interview with the tenants."275 These cases demonstrate that the owner of property may invoke the state trespass laws to eject undesirables if the property is truly "private" but, contrariwise, that the owner of property nominally "private" but in actuality open to the public has no such right.

Another series of cases, analogous to the problem here, holds that the homeowner acting individually can reject unwelcome guests at his doorstep; but that a city acting on behalf of its citizens can make blanket rejections if, and only if, the unwelcome guest contributes nothing of value to himself, the homeowner, or society. Many cities have sought to protect their citizen home-owners from unwelcome door-to-door salesmen by making it illegal for solicitors, peddlers, hawkers, and the like to go upon private residences without prior invitation of the householder. When the city of Struthers sought to apply this type of ordinance to a Jehovah's Witness distributing hand bills advertising a religious meeting, the Supreme Court held the city action unconstitutional: ${ }^{270}$

Freedom to distribute information to every citizen wherever he desires to receive it is so clearly vital to the preservation of a free society that . . . it must be fully preserved. The dangers of distribution can so easily be controlled by traditional legal methods, leaving to each householder the full right to decide whether he will receive strangers as visitors, that stringent prohibition can serve no purpose but that forbidden by the Constitution, the naked restriction of the dissemination of ideas.

When the city of Alexandria sought to apply this type of ordinance to a magazine salesman, the Supreme Court sustained the constitutionality of the city's action. Pointing out that the prior Struthers case involved "the free distribution of an invitation to religious services," whereas here was involved the commercial solicitation of mass magazine subscriptions, the Court said: "It would be, it seems to us, a misuse of the great guarantees of free speech and free press to use those guarantees to force a community to admit the solicitors of publications to the home premises of its residents." ${ }^{377}$ Justices Black and Douglas dis-

\footnotetext{
${ }^{275}$ Commonwealth v. Richardson, 313 Mass. 632, 48 N.E.2d 678 (r943).

${ }^{270}$ Martin v. Struthers, 319 U.S. 141, 146-147 (1943).

${ }^{277}$ Breard v. Alexandria, 34I U.S. 622, 645 (195I).
} 
sented from this holding with the statement that "The constitutional sanctuary for the press must necessarily include liberty to publish and circulate." They too, however, would draw the line permitting city punishment for home trespass according to the societal value of the intrusion. Justice Black said: "Of course I believe that the present ordinance could constitutionally be applied to a merchant who goes from door to door selling pots."278

There is yet another area of conduct where society sometimes prohibits individuals from precluding unwelcome guests: the area of private associations. As a general proposition, clubs, societies, and organizations can admit to membership or reject from membership whomever they please for whatever reasons they please. This unlimited power to exclude from membership is premised on the supposed personal nature of the relationship and the futility of attempting to force one man's companionship on another. ${ }^{279}$ But the seriousness of the consequences of an exclusion or expulsion varies greatly in different kinds of associations: ${ }^{280}$

Expulsion from a secret society, or the refusal of the grand lodge to give its password to the delegate of a subordinate lodge, or the revocation of the charter of a college sorority, leave no permanent wounds. . . But the skilled workman who is thrown out of his trade union, the physician expelled from the medical association, or the broker expelled by the stock exchange, will often find is very hard to earn a livelihood.

The degree to which the "private society" performs a function or service vital to the excluded individual determines the line drawn by the courts when asked to grant relief to a person excluded from societal membership. This is demonstrated in a series of cases involving labor unions, long considered as being no different from any other fraternal organizations and therefore governed by the same set of legal rules. ${ }^{281}$ A union of bricklayers, for example, is free to exclude Negro bricklayers from membership on the theory that the union represents and bargains only for its members and because there is nothing to prevent Negro bricklayers from organizing a union of their own. ${ }^{282}$ However, when the nature of the industry is such that two or more unions cannot exist side

\footnotetext{
${ }^{378} I d$. at 650 .

${ }^{279}$ Summers, The Right to Join a Union, 47 Colum. L. REv. 33, 37 (1947).

${ }^{280}$ Chafee, The Internal Affairs of Associations Not for Profit, 43 HARv. L. REv. 993, 1021 (1930).

${ }_{281}$ "The legal status of unions is practically identical with that of fraternal organizations." WITTE, Government in LABOR Disputes I 3 -I4 (1932).

${ }^{282}$ Ross v. Ebert, 275 Wis. 523,82 N.W.2d $3 \times 5$ (1957).
} 
by side, and as a consequence, the union chosen by a majority of the employees speaks and acts on behalf of all employees, the union is then required to represent all on an equal basis-white member and Negro nonmember alike. ${ }^{283}$ And when membership in a union becomes a condition of employment, the union that functions under state protection and holds itself out to represent the needs of employees loses its status as a private organization and is obligated to accept all qualified applicants for membership. ${ }^{284}$

A final analogy to the situation at hand is found in the racial restrictive covenant cases. A racial restrictive covenant is an agreement entered into by fellow property owners whereby each agrees not to sell to a member of a designated race. The cases arose when white property owners sold to Negroes and neighboring white property owners asked the courts to enforce the covenants by ejecting the Negro occupants. The Supreme Court ruled that the requested judicial relief unconstitutionally deprived Negroes of "the same right . . . as is enjoyed by white citizens ... to ... purchase, lease, sell, hold, and convey real and personal property."285 The Court pointed out that "these are not cases, as has been suggested, in which the states have merely abstained from action, leaving private individuals free to impose such discriminations as they see fit. Rather, these are cases in which States have made available to such individuals the full coercive power of government ...."288 The Court concluded that "The Constitution confers upon no individual the right to demand action by the state which results in the denial of equal protection of the laws to other individuals."287 In reaching this conclusion, the Court relied upon Marsh v. Alabama, ${ }^{288}$ which prohibited

${ }^{283}$ Steele v. Louisville \& N.R.R., 333 U.S. I92 (1944).

${ }^{284}$ James v. Marinship Corp., 25 Cal. 2d 721, I55 P.2d 329 (1945); Betts v. Easley, 161 Kan. 459, I69 P.2d 83 I (1946). The necessity that a Negro employee have a voice and a vote in the union which represents his economic interest justifies a state statute's prohibiting union discrimination. Railway Mail Ass'n v. Corsi, 326 U.S. 88 (1945). There the Court said:

"Appellant [union] contends that [the law] ... offends the due process clause of the Fourteenth Amendinent as an interference with its right of selection to meinbership ..... A judicial determination that such legislation violated the Fourteenth Amendment would be a distortion of the policy manifested in that amendment, which was adopted to prevent ... discrimination on the basis of race or color. We see no constitutional basis for the contention that a state cannot protect workers from exclusion solely on the basis of race, color or creed by an organization, functioning under the protection of the state, which holds itself out to represent the general business needs of employees." Id. at 9394.

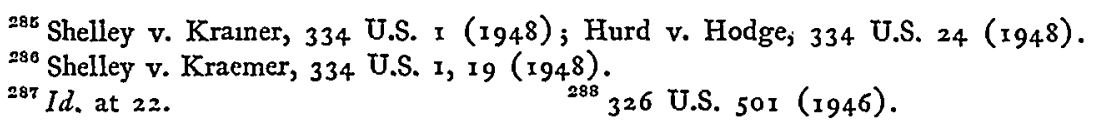


state judicial enforcement of trespass laws; upon Buchanan $v$. Warley, ${ }^{280}$ which invalidated a city statute prohibiting a white vendor from selling to a would-be Negro purchaser; upon Richmond v. Deans, ${ }^{200}$ which nullified a city ordinance prohibiting Negroes the right to seek out and purchase homes in a "white" neighborhood; and upon Oyama v. California, ${ }^{291}$ which declared unconstitutional a state law denying equal enjoyment of property rights to Japanese. The intermingled reliance on case authority involving state judicial and state legislative action makes it clear that if a state cannot command discrimination by legislative fiat, it cannot achieve the same result by judicial enforcement of individual discriminatory practices.

The above analogies indicate that the dime-store owners cannot seek judicial aid to remove undesired Negro patrons from their lunch counters. ${ }^{292}$ Today's restauranteur occupies a position analogous to that of the innkeeper in Merrie England and to that of the modern American trade union. He operates under state control and inspection, and performs a service that is vital to the general public. "Eating out" is no longer a social treat or family outing. Thousands of our citizens live in rented rooms with no kitchen facilities, and additional millions work in situations where they cannot go home for lunch. If these persons cannot eat in restaurants, they are deprived of the necessities of life. It smacks too much of Marie Antoinette to suggest that the combination of grocery stores and city parks provides a suitable alternative to the restaurant. The right of opportunity to eat at a restaurant is as basic as the right of employees to free self-organization, ${ }^{203}$ as basic as the right to union membership, ${ }^{294}$ as basic as the right of Jehovah's Witnesses to distribute religious handbills at the open front door of the homeowner, ${ }^{205}$ and fully as basic as the right to acquire suitable hous-

\footnotetext{
289245 U.S. 60 (I9I7).

${ }_{280}^{28}$ I U.S. 704 (1930).

201332 U.S. 633 (1948).

202 Whether or not the storekeepers can hire a private detective to eject Negro customers is a difficult and unresolved question. Marrone v. Washington Jockey Club, 227 U.S. 633 ( $191_{3}$ ), holds that a patron ejected with no more force than necessary from a race track has no cause of action in assault and battery. However, should an ejected Negro patron sue a restaurant owner for assault and battery, and should the restaurant owner defend on the theory that he does not serve Negroes, it is questionable that the fourteenth amendment would permit the state courts to recognize such a defense. See Rice v. Sioux City Memorial Park Cemetery, 349 U.S. 70 (1955), discussed in note 257 supra.

${ }^{203}$ See Republic Aviation Corp. v. NLRB, 324 U.S. 793 (1945).

${ }_{204}$ See James v. Marinship Corp., 25 Cal. 2d 721, I55 P.2d 329 (1945).

${ }^{208}$ See Martin v. Struthers, 3 I9 U.S. 141 (1943).
} 
ing. ${ }^{298}$ All these mentioned rights have been held to be paramount to the right of privacy, the right to enforce "no trespass" rules, and the right of freedom of choice in association. Moreover, on the other side of the coin, it should be noted that today's typical restaurant is no longer a place where habitués gather at appointed tables with old cronies for a glass of beer, a game of whist, and an opportunity to discuss events of the day. Today's typical restaurants are, in the literal sense of the word, "public houses." To paraphrase the Supreme Court in Marsh v. Alabama, ${ }^{207}$ today's restauranteur, for his advantage, has opened his property for use by the public in general, and his rights have become circumscribed by the statutory and constitutional rights of the public in general. Ownership in these circumstances no longer means absolute dominion.

There is, therefore, ample legal ground for holding that the application of state trespass laws to the dime-store demonstrators wrongfully deprives them of fundamental rights of citizenship protected by federal statute and constitutional amendment. Whether or not the courts will reach this result remains to be seen. ${ }^{298}$ In the meantime, it is well to mark the words of Dr. Frank Graham on this problem: ${ }^{299}$

When human rights are conceived as trespassing on property rights it should be recalled that property rights are securer and individual rights are freer when human rights are fairer.

\footnotetext{
${ }^{200}$ See Shelley v. Kraemer, 334 U.S. I (I948).
}

207326 U.S. 501, 505-06 (1946).

${ }^{298}$ The sit-in demonstrators have been much condemned for adopting "illegal" tactics. It is commented that the violation of trespass laws has set the Negro cause back several years. It should be noted, however, that it was not until Negroes had "trespassed" into pullman cars, into railroad dining cars, into "white only" waiting rooms, into the "white" sections of buses, that their right to nondiscriminatory service was established in the courts. Indeed, "trespass" is the only way to test the legality of "white only" lunch counters. See, e.g., Evers v. Dwyer, $35^{8}$ U.S. 202 (1958), where the city of Memphis moved to dismiss a suit involving segregated bus service on the ground that there was no "actual controversy" because the Negro litigant had ridden the bus only once and thus had no standing to bring the suit. More important, perhaps, is the fact that critics of the "trespass" technique overlook the failure of all but the direct approach to achieve for the Negro his rightful place in a democratic society, Constitutional amendments, congressional enactments, and Supreme Court decisions have failed to achieve their desired purpose. It was inevitable, therefore, that a more direct approach would be sought; fortunately it was a Christian nonviolent approach. "Many Negroes recognize the necessity for creating discord to alter established community patterns, but they strongly desire that controls be built in, so that neither they nor their adversaries would find themselves engaged in mutual destruction." King, The Burning Truth In The South, The Progressive, May 1960, p. 9 .

${ }^{200}$ Address, United Nations Model Assembly, Williamsburg, Va., March I1, 1960. Carolina Times (Durham, N.C.) March I9, I960, p. 2, col. 3 . 